\title{
6. SITE 498: MIDDLE AMERICA TRENCH LOWER SLOPE ${ }^{1}$
}

\author{
Shipboard Scientific Party ${ }^{2}$
}

\section{HOLE 498}

Date occupied: 5 June 1979

Date departed: 6 June 1979

Time on hole: $24.7 \mathrm{hr}$.

Position: $12^{\circ} 42.68^{\prime} \mathrm{N} ; 90^{\circ} 54.94^{\prime} \mathrm{W}$

Water depth (sea level; corrected m, echo sounding): 5478

Water depth (rig floor; corrected m, echo sounding): 5488

Bottom felt (m, drill pipe): 5497

Penetration (m): 60

Number of cores: 2

Total length of cored section (m): 12.5

Total core recovered $(\mathrm{m}): 3.87$

Core recovery $(\%): 30.9$

Oldest sediment cored:

Depth sub-bottom (m): 60

Nature: Mud

Age: Late Quaternary

Basement: Not reached

\section{HOLE 498A}

Date occupied: 7 June 1979

Date departed: 10 June 1979

Time on hole: 3.75 days

Position: $12^{\circ} 42.68^{\prime} \mathrm{N} ; 90^{\circ} 54.94^{\prime} \mathrm{W}$

Water depth (sea level; corrected $\mathrm{m}$, echo sounding): 5478

Water depth (rig floor; corrected m, echo sounding): 5488

Bottom felt (m, drill pipe): 5497

Penetration (m): 316.5

Number of cores: 16

\footnotetext{
${ }^{1}$ Aubouin, J., von Huene, R., et al., Init, Repts. DSDP, 67: Washington (U.S. Govt. Printing Office).

2 Roland von Huene (Co-Chief Scientist), U.S. Geological Survey, Menlo Park, California; Jean Aubouin (Co-Chief Scientist), Département de Géologie Structurale, Université Pierre et Marie Curie, Paris, France; Jacques Azéma, Département de Géologie Structurale, Université Pierre et Marie Curie, Paris, France; Grant Blackinton, Hawaii Institute of Geophysics, University of Hawaii, Honolulu, Hawaii; Jerry A. Carter, Hawaii Institute of Geophysics, University of Hawaii, Honolulu, Hawaii; William T. Coulbourn, Deep Sea Drilling Project, Scripps Institution of Oceanography, La Jolla, California; Darrel S. Cowan, Department of Geological Sciences, University of Washington, Seattle Washington; Joseph A. Curiale, Department of Geology, University of Oklahoma, Norman, Oklahoma (present address: Union Oil Company of California, P.O. Box 76, Brea, Ca.); Carlos A. Dengo, Department of Geology and Center for Tectonophysics, Texas A\&M University, College Station, Texas; Richard W. Faas, Department of Geology, Lafayette College, Easton, Pennsylvania; William Harrison, Department of Geology, University of Oklahoma, Norman, Oklahoma; Reinhard Hesse, Lehrstuhl für Geologie, Technische Universität, Münich, Federal Republic of Germany, and Department of Geological Sciences, McGill University, Montreal, Quebec, Canada: Donald M. Hussong. Hawaii Institute of Geophysics, University of Hawail, HonoTexas (present address: Lamont-Doherty Geological Observatory, Palisades, New York); Nikita Muzylöv, Geological Institute, U.S.S.R. Academy of Sciences, Moscow, U.S.S.R; Tsunemasa Shiki, Department of Geology and Mineralogy, Faculty of Science, Kyoto University, Kyoto, Japan: Peter R. Thompson, Lamont-Doherty Geological Observatory, Palisades, New York; and Jean Westberg, Geological Research Division, Scripps Institution of Oceanography, La Jolla, California.
}

Total length of cored section $(\mathrm{m}): 142.5$

Total core recovered $(\mathrm{m}): 46.54$

Core recovery (\%): 32.6

Oldest sediment cored:

Depth sub-bottom (m): 316

Nature: Mudstone

Age: Early middle Miocene

Basement: Not reached

Principal results (Holes 498 and 498A): Comparison with Hole 494A reveals disparity between Miocene lithologies at these two closely spaced holes.

The bathymetry from Kana Keoki seismic records obtained after drilling at Site 494 suggests that Site 494 may be located in a zone of faulting transverse to the strike of the trench.

At Site 498 , drilling was done about $1.8 \mathrm{~km}$ east-southeast and along strike from Site 494 in a less faulted but structurally identical position (Fig. 1). Important gaps in the stratigraphic section at Site 494 were not filled at Site 498 nor was the underlying oceanic section sampled, because the recovery of gas hydrate forced us to abandon the site prior to reaching depths greater than penetrated at Site 494.

The mud and mudstone from the top 200 meters at Site 498 resemble those at Site 494. Abundant Pleistocene biogenic sediment transported from upslope is underlain by a Miocene unit of biogenic sediment. However, the Miocene lithologic succession is unlike that of equivalent-age rock from Site 494. The unbrecciated part of the section is dark olive gray mudstone, although chips of the familiar blue gray Miocene mudstone of Site 494 are abundant in the drilling breccia, which constitutes most of the recovered material. Additionally, at Site 498, the Miocene section is thicker than at Site 494 . The poor core recovery and drilling conditions below 200 meters sub-bottom depth at Site 498 indicate that fracturing is well developed.

Gas hydrates were encountered at about 310 meters sub-bottom depth. The single occurrence of hydrates was accompanied by a rapid decrease of the methane-ethane ratio. The presence of hydrates was confirmed by measuring pressure as the hydrate came to ambient temperature, and from this value, calculating the relative volumes of gas and water.

\section{BACKGROUND AND OBJECTIVES}

Site 498 is located on the landward slope of the Middle America Trench in about 5480 meters of water, on a narrow terrace about 400 meters above and $4 \mathrm{~km}$ from the adjacent trench axis. That position is about 1.3 miles east-southeast of Site 494. Projection of submarine morphology down strike suggests a similar geology. On bathymetric and seismic records made by Kana Keoki, Site 494 appears to be located in a zone of faulting transverse to the trend of the trench axis. Brecciation of the country rock may be a reason for low core recovery at Site 494 . We believed Site 498 to be located further from the suspected transverse fault. The site was selected on the basis of the data at hand; subsequently a post-drilling, Seabeam survey (Aubouin et al., this volume) indicated a geometry of features somewhat different from that upon which our decisions were based. 


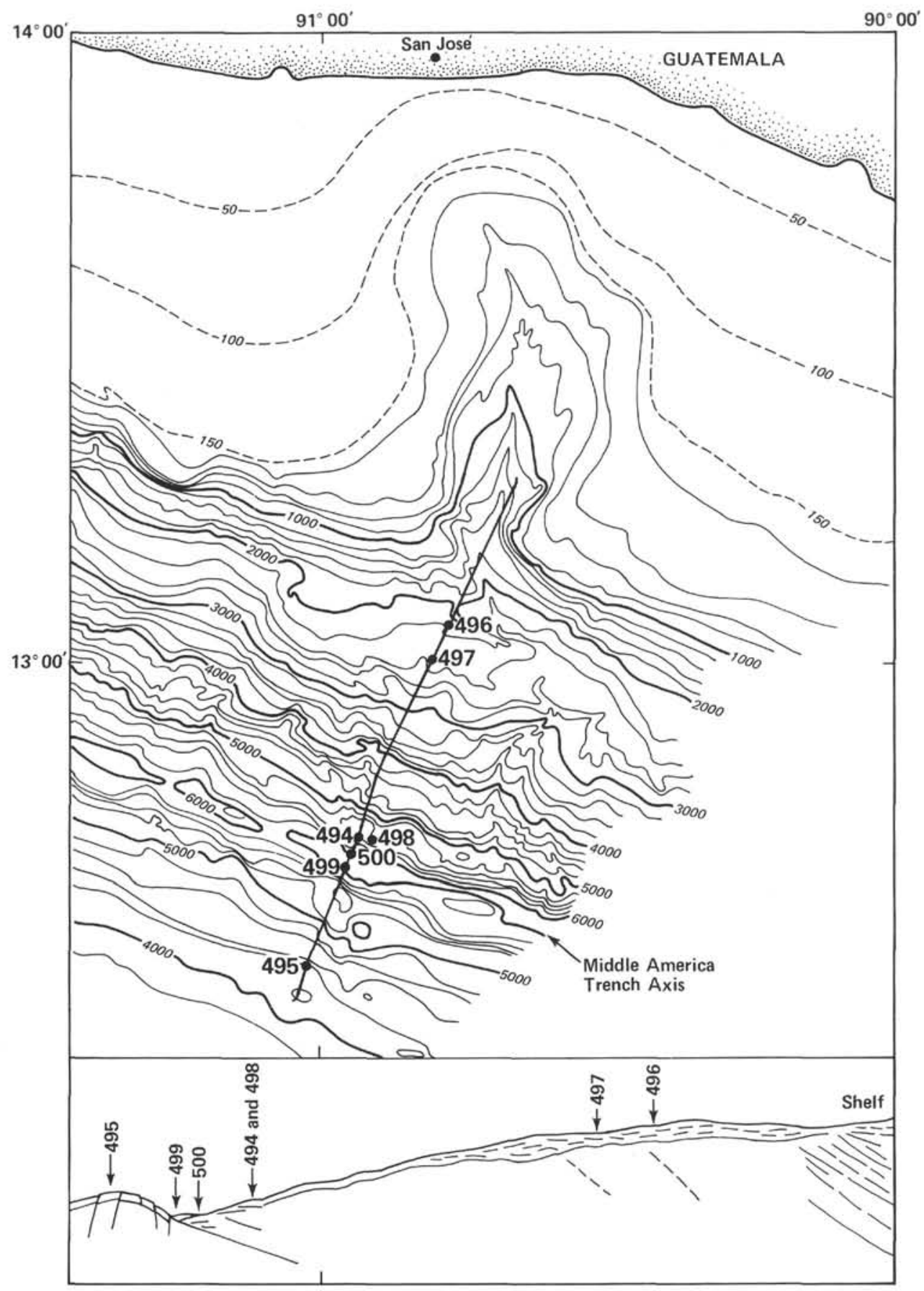

Figure 1. Location map and cross section showing position of Site 498.

One objective at Site 498 was to obtain more complete stratigraphic information through better core recovery than was possible at 494 . Recovery at 494 was good above 200 meters, and because Site 498 is essentially an offset of Site 494, the uppermost interval was spot cored to gain much needed time. Other objectives below 200 meters were to recover the Miocene/Eocene contact and the Eocene/Cretaceous contact, as well as the Cretaceous contact with the underlying igneous rock. Drilling at Site 494 did not establish whether these con- tacts are faults or unconformities. The absence of logs at 494 made it imperative to get them at 498 .

The principal objective was to drill deeper than at Site 494, which had been abandoned because of drilling conditions. Below the section sampled at 494 are layered seismic reflectors, presumably rock or, more likely, a younger sediment section that was underthrust beneath the Cretaceous and igneous rock. The oceanic crust immediately seaward of the trench is Miocene or possibly Oligocene. At Site 498 we hoped to penetrate the upper 
plate of a subduction zone and perhaps sample underlying trench and pelagic sediment and basalt.

\section{OPERATIONS}

Glomar Challenger departed Site 497 on 6 June, 1430 L (Local Time), steaming along the Guatemala transect until Site 494, where a beacon was still operating. Using the beacon as a navigational aid, Glomar Challenger steamed east-southeast $\left(108^{\circ}\right)$ and dropped a new 16 $\mathrm{kHz}$ beacon 1.1 miles from Site 494 .

After a short site survey for the purpose of bathymetric and seismic profiling, a position 500 feet southsouthwest $\left(200^{\circ}\right)$ of the beacon was selected for drilling.

The first core was recovered at Site 498, on 6 June at $1153 \mathrm{~L}$, from a depth of 5497 meters (Table 1). Coring continued until 9 June, when gas hydrate that was recovered in Core 15 (310 meters sub-bottom depth) caused us to abandon the hole. Logging was attempted, but the bit failed to release; in the process of trying to release the bit a second time, the sand line snarled and parted, ending chances for logging. The Challenger then departed Site 498, did a short geophysical traverse of the trench axis, and headed for the emergency pickup of chemicals at Acajutla.

\section{LITHOSTRATIGRAPHY}

Site 498 is located at a water depth of 5497 meters on a small terrace $4 \mathrm{~km}$ landward of the Middle America Trench axis and about $2 \mathrm{~km}$ east of Site 494. The offset was made to avoid a suspected transverse fault near Site 494 and thereby improve core recovery. Because Sites 494 and 498 are so close to each other, the differences in our drilling results at those two locations are particularly interesting.

There is a systematic decrease in diatom percentages near 200 meters sub-bottom depth and an increase in the proportion of volcanic glass near 220 meters. These changes would not, in themselves, provide sufficient cause for a stratigraphic separation were it not that at nearly the same level, 223 meters, a Pliocene/Miocene contact was recorded in Hole 494A. Thus at this boundary the section at Site 498 is split into two units in spite of the generally uniform combination of dark olive gray (5Y 3/2) muds and mudstones, with lesser quantities of blue gray (5Y 5/1) mudstone (Fig. 2). The recovery, only $32 \%$ of the section drilled, and the brecciated rubble retrieved provide scanty information about the geology at Site 498.

Unit 1 (Core 1 to Core 2, Hole 498; Core 1 to Core 5, Section 1, Hole 498A; 0-213 m sub-bottom depth; Quaternary to Pliocene)

The uppermost muds and mudstones at Site 498 generally correspond to those of the upper two units at Site 494. These diatomaceous sediments resemble the slope blanket recovered at all previous Leg 67 sites on the Guatemalan continental margin. The color is the same dark olive gray, and the biogenic component includes varying proportions of diatoms, nannofossils, and plant debris. There are also some patches of volcanic ash in the unit.

\section{Unit 2 (Core 5, Section 1 to Core 16, Hole 498A; 213-321.5 m sub-bottom depth; Miocene)}

Cores 5 and 8 are the only portions of Unit 2 where recovery was good and the rock was not brecciated by drilling. Biscuiting, however, disrupted most of the primary features of these bioturbated mudstones. The first micritic limestone of the stratigraphic section, analogous to those rocks described at Hole 494A, was recovered at 219.5 meters sub-bottom depth (top of Core 5, Section 6). Micrites recur at 242 meters sub-bottom depth (top of Section 2, Core 8) and are spread throughout the drill breccia of Cores 10 to 14 . Blue gray mudstones first appear in the drill breccia of Core 4 and recur in all the deeper brecciated sections.

The Site 498 mudstones are at the same sub-bottom depths as Units 3, 4, and 5 of Site 494. At Site 494, rocks span the interval from lower Miocene to Upper Cretaceous and represent a variety of marine facies. No such sequence is observed at Site 498 . The disparity between the lithologic columns of the two sites indicates a high degree of variability along the strike of the inner trench slope of the Guatemalan margin. The fact that core re-

Table 1. Coring summary for Holes 498 and $498 \mathrm{~A}$

\begin{tabular}{cccccccr}
\hline Core No. & $\begin{array}{c}\text { Date } \\
\text { (June, 1979) }\end{array}$ & $\begin{array}{c}\text { Local Time } \\
\text { (L) }\end{array}$ & $\begin{array}{c}\text { Depth from } \\
\text { Drill Floor } \\
\text { (m; top-bottom) }\end{array}$ & $\begin{array}{c}\text { Sub-bottom } \\
\text { Depth } \\
\text { (m; top-bottom) }\end{array}$ & $\begin{array}{c}\text { Length } \\
\text { Cored } \\
\text { (m) }\end{array}$ & $\begin{array}{c}\text { Length } \\
\text { Recovered } \\
\text { (m) }\end{array}$ & $\begin{array}{c}\text { Recovery } \\
(\%)\end{array}$ \\
\hline Hole 498 & & & & & & & \\
1 & 6 & 1153 & $5497.0-5500.0$ & $0.0-3.0$ & 3.0 & 2.97 & 99 \\
2 & 6 & 1408 & $5547.0-5557.0$ & $50.5-60.0$ & 9.5 & 0.90 & 9 \\
Hole 498. & & & & & & & \\
1 & 7 & 0740 & $5528.5-5533.0$ & $31.5-36.0$ & 4.5 & 0.78 & 17 \\
2 & 7 & 1350 & $5595.0-5604.5$ & $98.0-107.5$ & 9.5 & 1.44 & 15 \\
3 & 7 & 1902 & $5652.0-5661.5$ & $155.0-164.5$ & 9.5 & 0.62 & 6 \\
4 & 8 & 0112 & $5699.5-5709.0$ & $202.5-212.0$ & 9.5 & 1.82 & 19 \\
5 & 8 & 0301 & $5709.0-5718.5$ & $212.0-121.5$ & 9.5 & 9.32 & 98 \\
6 & 8 & 0451 & $5718.5-5728.0$ & $221.5-231.0$ & 9.5 & 0.03 & $>1$ \\
7 & 8 & 0650 & $5728.0-5737.5$ & $231.0-240.5$ & 9.5 & 5.45 & 57 \\
8 & 8 & 0856 & $5737.5-5747.0$ & $240.5-250.0$ & 9.5 & 7.94 & 83 \\
9 & 8 & 1121 & $5747.0-5756.5$ & $250.0-259.5$ & 9.5 & 0.10 & 1 \\
10 & 8 & 1410 & $5756.5-5766.0$ & $259.5-269.0$ & 9.5 & 9.79 & 100 \\
11 & 8 & 1954 & $5766.0-5775.5$ & $269.0-278.5$ & 9.5 & 3.44 & 36 \\
12 & 8 & 2242 & $5775.5-5785.0$ & $278.5-288.0$ & 9.5 & 2.08 & 22 \\
13 & 9 & 0138 & $5785.0-5794.5$ & $288.0-297.5$ & 9.5 & 0.76 & $>1$ \\
14 & 9 & 0415 & $5794.5-5804.0$ & $297.5-307.0$ & 9.5 & 0.05 & $>1$ \\
15 & 9 & 0719 & $5804.0-5813.5$ & $307.0-316.5$ & 9.5 & 2.25 & 24 \\
16 & 9 & 0924 & $5813.5-5823.0$ & $316.5-321.5$ & 5.0 & 0.0 & 0 \\
H1 & 7 & 0503 & Wash Core & $31.5-321.5$ & & 5.41 & \\
\hline
\end{tabular}



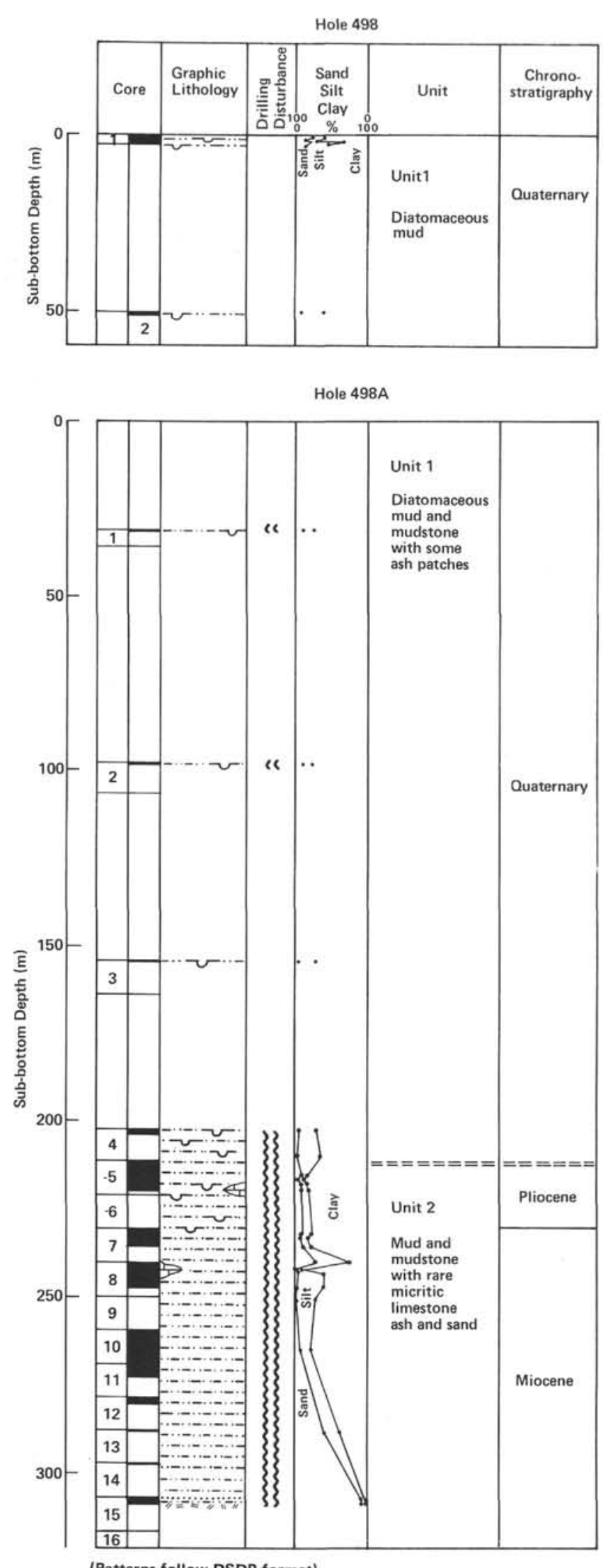

(Patterns follow DSDP format)

Figure 2. Summary lithologic columns for Site 498. covery was so poor in an area that seismic reflection records show to be relatively undisturbed suggests either that the mudstones at Hole 498A are more highly microfractured than their counterparts at Hole $494 \mathrm{~A}$ or that in some manner the drilling operation at Hole 498A was more disruptive than at Hole 494A. The latter possibility hardly seems the case.

The presence of ice was the most dramatic difference between Sites 498 and 494 . On deck, the smoking, unopened barrel of Core 15 betrayed the now "predictable" association of gas hydrate and coarse-grained sediments from the continental margin at 300 to $\mathbf{4 0 0}$ meters sub-bottom depth (refer to the Organic Geochemistry section). Hydrates are associated with vitric sands sampled at $128 \mathrm{~cm}$ within Section 2 of Core 15, and the stratigraphic equivalent of those sands was not recovered at Site 494, less than $2 \mathrm{~km}$ away. The recovery of gas hydrate, low methane to ethane ratio, and zero recovery for Core 16 caused termination of drilling at Hole 498A.

\section{PHYSICAL PROPERTIES}

\section{Bulk Density and Water Content}

Two sedimentary units are clearly defined by these properties (Fig. 3). Unit 1 extends in Hole 498A from the mud line down through Core $4(38 \mathrm{~m})$ and is unconsolidated Quaternary clay. Water content is very high and bulk density very low. Unit 2, a lithified Pliocene mudstone, shows a significant reduction in water content and a corresponding increase in bulk density. The contrast in physical properties between the two units indicates that an unconformity or surface of nondeposition separates them.

\section{Sound Velocity}

Because of the limited recovery, the extremely poor condition of the material that was recovered, and the presence of gas, velocity measurements were limited to fragments of mudstones that may or may not have been in place. No profile is presented, but the velocities are listed in Table 2. Several measurements were made on some micritic limestone pebbles that were found in Core 12 , Section $1(5 \mathrm{~cm})-4.24 \mathrm{~km} / \mathrm{s}$, and in Sample 498A$13, \mathrm{CC}-3.46 \mathrm{~km} / \mathrm{s}$.

No unusual problems or phenomena emerged from this limited sampling. All velocities recorded appeared reasonable for the type of sediment and degree of induration. Table 3 summarizes the physical properties of this site.

\section{GEOPHYSICS}

Site 498 was located on the lowest of a series of terraces on the landward slope of the Middle America Trench (Fig. 4). The site is about 1.1 miles southeast of Site 494 in an area where seismic data from Kana Keoki (Fig. 5) indicate that the terrace is broader and smoother than at Site 494. Seismic profiles from Kana Keoki and Glomar Challenger show reflecting horizons that are more continuous below Site 498 than below 494, sug- 


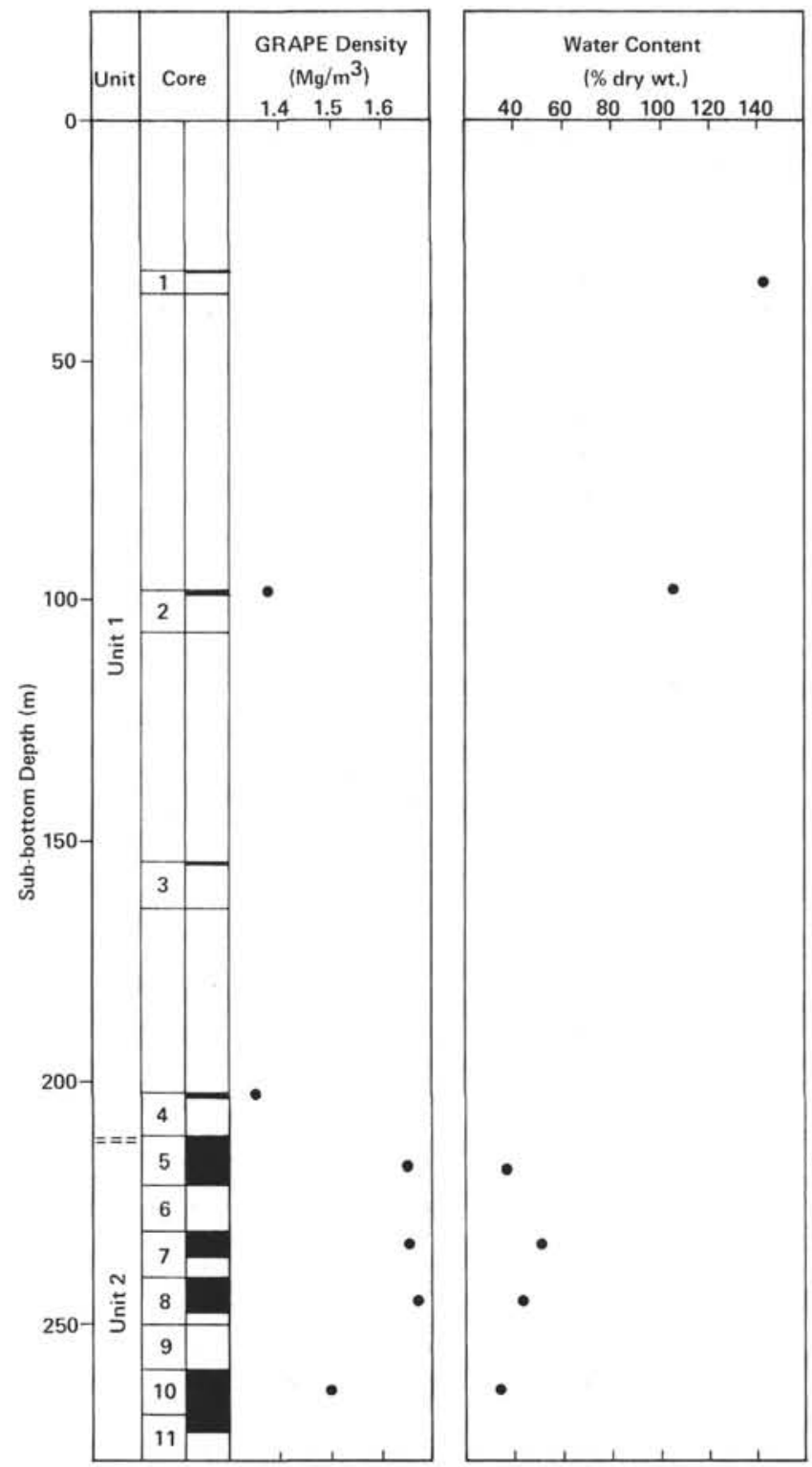

Figure 3. GRAPE density and water content for samples from Hole 498A.

Table 2. Compressional-wave velocities, Hole 498A.

\begin{tabular}{cccc}
\hline Core & Section & Interval $(\mathrm{cm})$ & $V_{p}(\mathrm{~km} / \mathrm{s})$ \\
\hline 4 & 1 & 110 & 1.44 \\
5 & 1 & 20 & 1.61 \\
5 & 1 & 87 & 1.77 \\
5 & 3 & 95 & 1.78 \\
7 & 2 & 75 & 1.72 \\
10 & 1 & 20 & 1.71 \\
12 & 2 & 30 & 1.52 \\
\hline
\end{tabular}

gesting that 494 may be at the intersection of two fault systems and that 498 is away from recognizable faults (Fig. 6).

Site 498 was situated close to Site 494 in order to drill the same section; by staying clear of obvious faults,
Table 3. Physical properties, Site 498.

\begin{tabular}{|c|c|c|c|c|c|c|}
\hline $\begin{array}{c}\text { Sample } \\
\text { (core-section } \\
\text { interval [cml) }\end{array}$ & $\begin{array}{c}\text { GRAPE } \\
\text { Wet-Bulk } \\
\text { Density } \\
\left(\mathrm{Mg} / \mathrm{m}^{3}\right)\end{array}$ & $\begin{array}{l}\text { P. Wave } \\
\text { Velocity } \\
(\mathrm{km} / \mathrm{s})\end{array}$ & $\begin{array}{c}\text { Acoustic } \\
\text { Impedance } \\
\left(\times 10^{5} \mathrm{~g} / \mathrm{cm}^{2} \cdot \mathrm{s}\right)\end{array}$ & $\begin{array}{l}\text { Shear } \\
\text { Strength } \\
(\mathrm{kPa})\end{array}$ & $\begin{array}{c}\text { Water } \\
\text { Content } \\
\text { ( } \% \text { dry wt.) }\end{array}$ & $\begin{array}{l}\text { Porosity } \\
\text { (vol. \%) }\end{array}$ \\
\hline \multicolumn{7}{|l|}{ Hole 498} \\
\hline $\begin{array}{l}1-2,50-52 \\
1-3,95-97\end{array}$ & $\overline{-}$ & $\overline{-}$ & $\overline{-}$ & $\begin{array}{l}3.87 \\
3.33\end{array}$ & ${ }^{143.6}$ & $\stackrel{78.3}{-}$ \\
\hline \multicolumn{7}{|l|}{ Hole 498A } \\
\hline $\begin{array}{l}1, \mathrm{CC} \\
5-1,80-82 \\
5-3,92-95 \\
7-2,76-78 \\
8-6,89-91 \\
10-1,18-20\end{array}$ & $\begin{array}{l}\bar{z} \\
\bar{z}\end{array}$ & $\begin{array}{l}\bar{z} \\
\bar{z}\end{array}$ & $\begin{array}{l}\bar{z} \\
\bar{z}\end{array}$ & $\begin{array}{l}5.10 \\
= \\
= \\
=\end{array}$ & $\begin{array}{r}104.8 \\
88.0 \\
38.4 \\
52.1 \\
41.0 \\
36.2\end{array}$ & $\begin{array}{l}72.5 \\
68.9 \\
49.1 \\
56.8 \\
50.9 \\
47.8\end{array}$ \\
\hline
\end{tabular}

we anticipated better recovery and deeper penetration. Once again, the principal objective was to penetrate through the slope deposits and drill into underlying ocean crust.

Challenger seismic data over Site 498 indicate that drilling stopped in a horizontally layered sequence (Fig. 6). The record indicates that at about twice the hole penetration there is a landward-dipping sequence of reflections that appears as a landward continuation of reflections from within the trench fill. The total subbottom depth of 321.5 meters is indicated on the time section of Figure 6 by assuming a sound velocity of 1500 $\mathrm{m} / \mathrm{s}$.

Contrary to expectations based on seismic data, recovery at Site 498 was poor-mostly gravels that are probably drilling breccia. The survey done by Kana Keoki in the vicinity of Sites 494 and 498 revealed nearvertical faults within the vicinity of the sites. It is difficult to establish a pattern of faults in the area, but at least two faults can be correlated between seismic lines across the terrace. The landward and seaward edges of the terrace are indicated by dotted lines in Figure 4.

\section{BIOSTRATIGRAPHY}

Two holes drilled at Site 498 produced little more than a heterogeneous mixture of brecciated sediment and rock of differing lithologies and ages. Below the Quaternary biogenic siliceous mud of Holes 498 and 498A, Cores 1 through 4 , most of the cores were made up of blue gray Miocene clasts (and dark olive gray mudstone clasts, also Miocene) in a matrix typically bearing younger fossils. The bottom of Hole 498A terminated in lower Miocene drill breccia (Fig. 7).

\section{Foraminifers}

Glomar Challenger drilling at Site 498 recovered sediments containing foraminifers that were deposited from the early Miocene to the late Quaternary. Typical planktonic species found included Neogloboquadrina eggeri, N. pachyderma, Globorotalia menardii, Globigerinoides ruber, G. sacculifer, and Globigerinita glutinata; all these species vied to provide Quaternary ages for Holes 498 (Cores 1 and 2) and 498A (Cores 1 through 4).

The last washed interval between Cores 3 and 4 $(164.5-202.5 \mathrm{~m})$ was partially recovered and labeled Core H1. The first section is placed in the Gauss on the basis of the planktonic foraminiferal species Globigerinoides obliquus, right-coiling Pulleniatina, and Globi- 


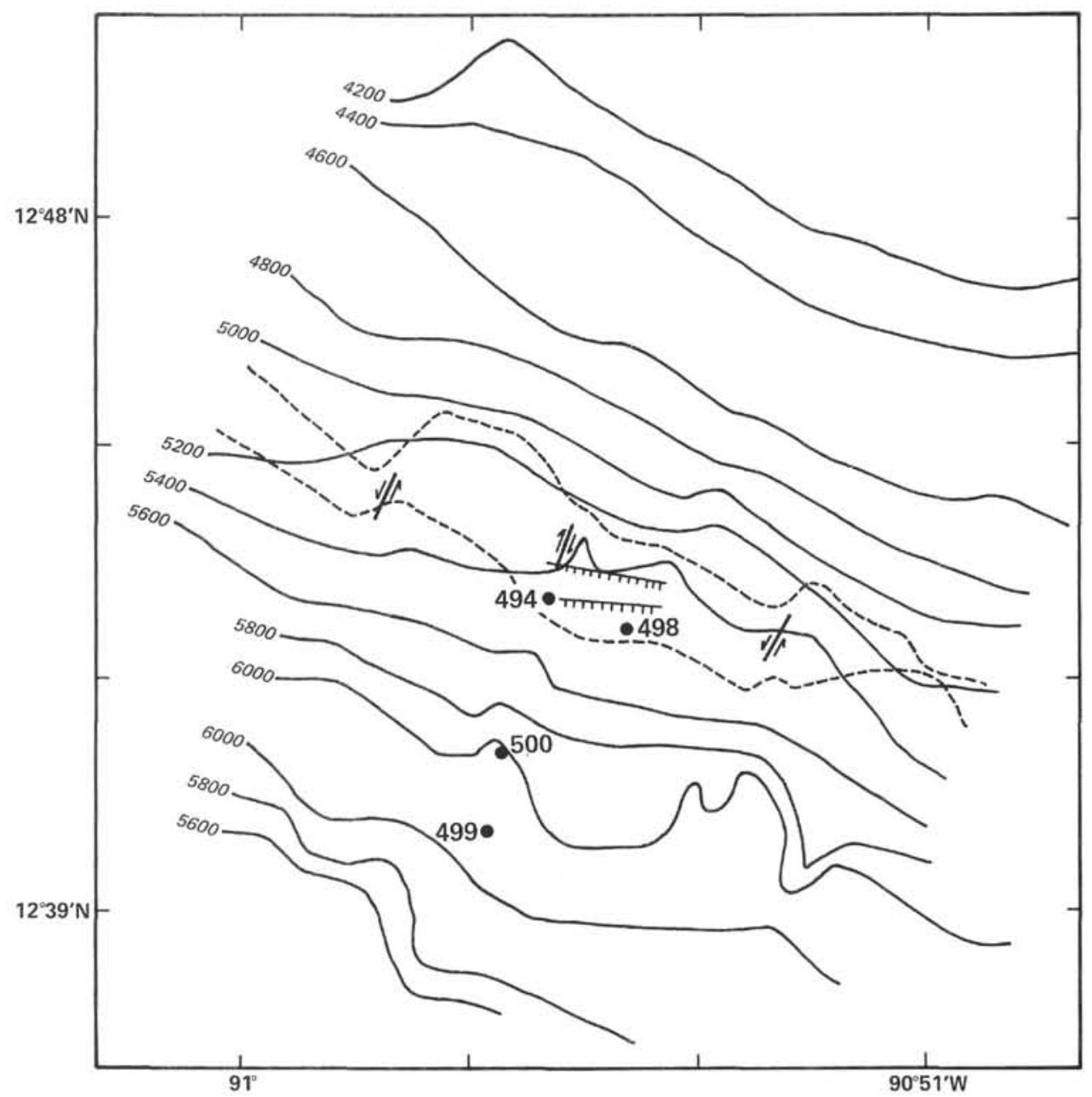

Figure 4. Bathymetry of the seaward edge of the Guatemalan margin.

gerina venezuelana. The core-catcher sample is identified as belonging to lower Miocene Zone N6 or N7, with recrystallized Catapsydrax dissimilis, Globorotalia continuousa, Globigerinita stainforthi, and Globoquadrina dehiscens. The stratigraphic position of this section is uncertain because of the washing process, although it may correspond to the interval in Hole 494A, Core 20.

Sediments that were recovered from Hole 498A, Cores 5 through 15 , generally have poorly preserved foraminiferal assemblages containing low abundances of specimens. Most of the assemblages are composed of lower bathyal benthic species such as Uvigerina senticosa, Pyrgo, Stilostomella, Melonis pompilloides, M. affinis, Pullenia bulloides, and Globobulimina pacifica; planktonic foraminifers were typically long-ranging forms that gave only approximate ages. The Pliocene was identified by taxa including Globorotalia exilis, Neogloboquadrina humerosa, and left-coiling Pulleniatina. The upper Miocene typically had Globorotalia plesiotumida and Globigerina venezuelana; the middle Miocene had Globorotalia peripheroronda, G. siakensis, Globoquadrina altispira, and Globigerinoides subquadratus; the lower Miocene was recognized by the occurrence of Catapsydrax dissimilis.
The bottom of Hole 498A (Core 15, Section 1) penetrated a coarse, well-sorted sand. Foraminifers were rare and had to be concentrated by heavy liquid separation using trichloethylene. Planktonic species collected include Globigerinoides triloba, Globorotalia siakensis, Globigerina decoraperta, and Globorotalia peripheroronda, all indicating the middle Miocene. Benthic taxa indicated a variety of water depths from lower to middle bathyal or perhaps shallower (deep water: Uvigerina senticosa, Melonis affinis, Stilostomella, Sphaerodina bulloides; shallow water: Amphistegina, Lenticulina, Anomalina, Eponides tenera). The average derivation level for these foraminifers is about 1500 meters, but the presence of a small gastropod near the top of Core 15, Section 1 suggests that the sand could be quite shallow, perhaps from the shelf.

\section{Radiolarians}

Most of the poorly recovered cores of Site 498 are drilling breccia composed of a mixture of lithologies and ages. Radiolarians are moderately well preserved but very diluted by abundant terrigenous material; consequently stratigraphic determinations are difficult. 


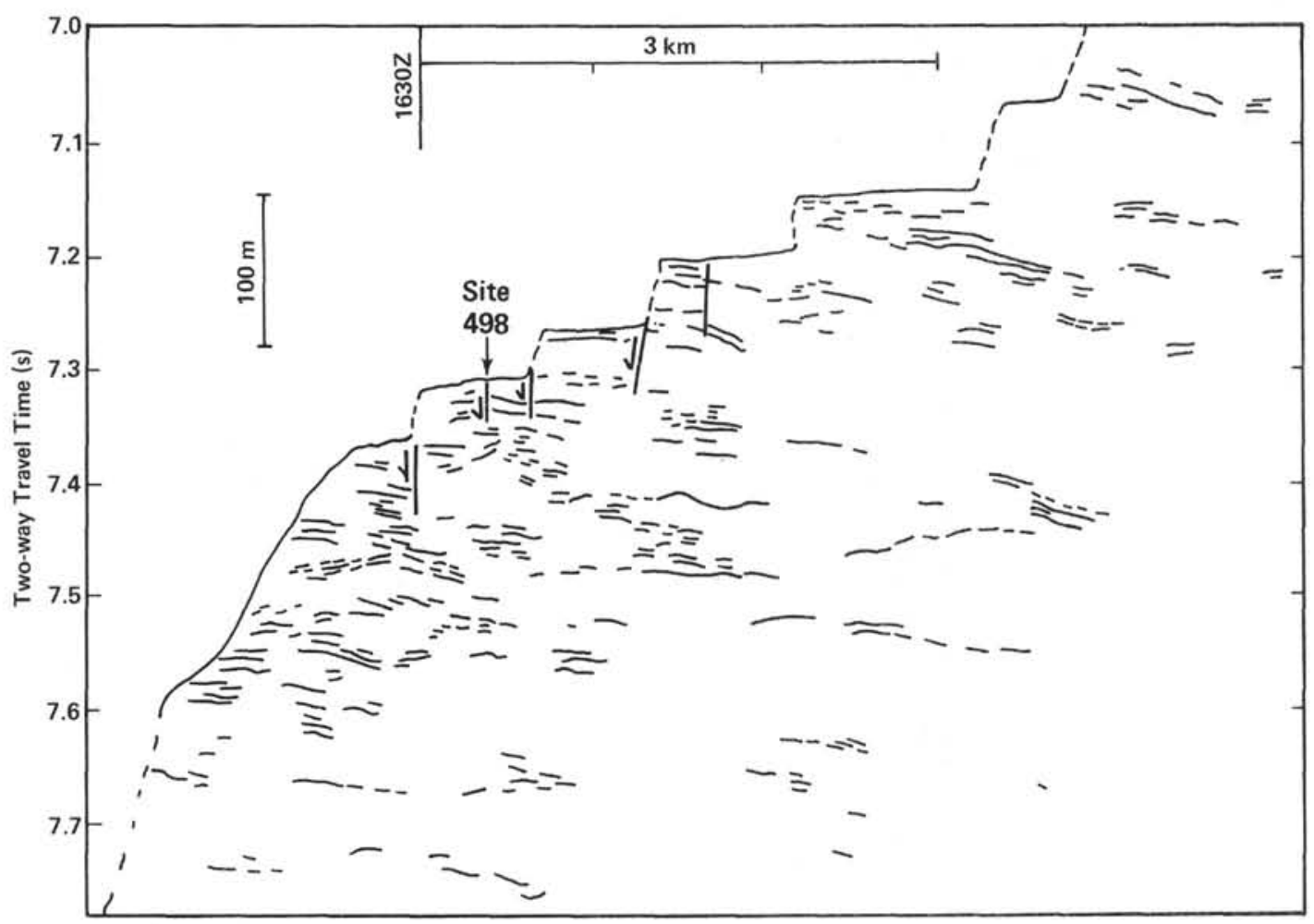

Figure 5. Tracing of a single-channel seismic reflection record made by Kana Keoki, illustrating the setting of Site 498 .

(Vertical exaggeration, 8:1.)

Typical Quaternary assemblages were found in Cores 1 and 2 at Hole 498 and in Cores 2 and 3 at Hole 498A. The presence of Axoprunum angelinum below Section 498-2-1 indicates an age greater than $400,000 \mathrm{yr}$. Eocene reworking (Podocyrtis mitra) was found in Section 498-2-1. Eocene radiolarians were also found in the Quaternary of nearby Site 494.

Blue clasts from Core 498A-H1, treated separately from the Quaternary matrix, yielded lower Miocene radiolarians: Calocycletta virginis, Cyrtocapsella cornuta, Didymocyrtis tubaria, Eucyrtidium diaphanes, and Lychnocanoma elongata.

Sample 498A-5-1, 80-82 cm appears to be upper middle Miocene, because of the co-occurrence of Didymocyrtis laticonus and $D$. antepenultima in nearly equal numbers and the presence of Lithopera renzae. An older assemblage in Sample 498A-5-6, 136-137 cm is considered uppermost lower Miocene because of the presence of Calocycletta costata and Liriospyris stauropora. Because of the sparseness of the young radiolarian assemblages and their rather poor preservation, the Miocene of Core 5 may completely mask a younger age.

Sample 498A-7-1, 40-42 cm, though sparse and poorly preserved, appears to be younger than Core 5 of Hole 498A, probably from the upper Miocene Stichocorys peregrina Zone. Sample 498A-7-4, 30-32 cm contains very rare specimens from the middle Miocene Diartus petterssoni Zone. The presence of Didymocyrtis avita, Spongaster tetras, Stichocorys peregrina, Lamprocyrtis nigriniae, and Theocorythium trachelium in Samples
498A-8-7, 24-26 cm and 498A-9,CC suggests the Pliocene or Quaternary, although these are single occurrences in very sparse assemblages. Hole 498A Cores 10 through 15 are highly disturbed drilling breccia with very little recovery. Radiolarians are extremely rare, and lower Miocene through Pliocene species are mixed.

\section{Nannoplankton}

Nannoplankton assemblages are characterized by contamination and different degrees of abundance, ranging from complete absence to common; preservation is good as a rule.

The oldest sediments penetrated are upper lower Miocene. Reworked fragments of middle or lower Miocene clay are present at different stratigraphic levels in the holes.

Samples 498A-2,CC and 498A-4-1, $100 \mathrm{~cm}$ contain Pleistocene assemblages with small Gephyrocapsa and Emiliania, Cyclococcolithina leptopora, and Helicopontosphaera kamptneri. Mixed with that assemblage are lower middle Miocene nannoplankton found in fragments of blue clay on the same stratigraphic level: Discoaster deflandrei, D. adamanteus, C. floridana, Sphenolithus moriformis. Sample 498A-5-3, $60 \mathrm{~cm}$ contains a lower Pliocene assemblage with very rare $D$. brouweri, ?Sphenolithus sp., C. leptopora, H. kamptneri.

A reworked assemblage from the lower middle Miocene Sphenolithus heteromorphus Zone was found in Sample 498A-5,CC, containing index species D. exilis, $D$. deflandrei, D. variabilis. A good assemblage of up- 


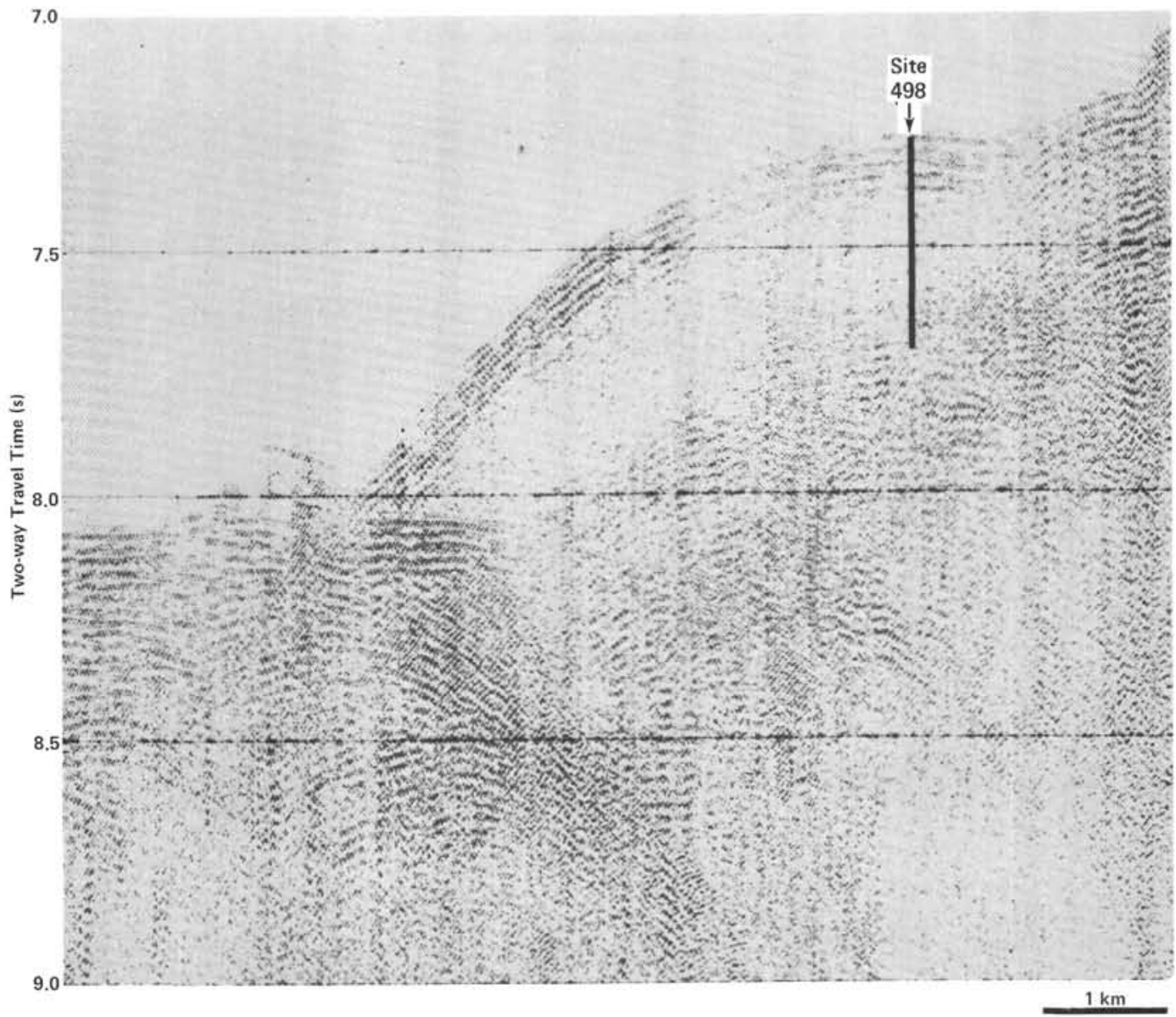

Figure 6. Seismic reflection record showing location of Site 498.

\begin{tabular}{|l|l|l|l|}
\hline Series & $\begin{array}{l}\text { Sample } \\
\text { (hole-core) }\end{array}$ & $\begin{array}{l}\text { Approximate } \\
\text { Sub-bottom } \\
\text { Depth of } \\
\text { Boundary }(\mathrm{m})\end{array}$ & Basis for Boundary Position \\
\hline Quaternary & $\begin{array}{l}498-1 \rightarrow 2, \text { and } \\
498 \mathrm{~A}-1 \rightarrow 4\end{array}$ \\
\hline Pliocene & $498 \mathrm{~A} \cdot 5$ & $\begin{array}{l}\text { Top of Globigerinoides obliquus } \\
\text { Top of Discoaster brouweri Zone }\end{array}$ \\
\hline Miocene & $498 \mathrm{~A}-7 \rightarrow 15$ \\
\hline
\end{tabular}

Figure 7. Stratigraphic series at Site 498.

per Miocene Discoaster quinqueramus is contained in Sample 498A-7-3, 32-34 cm.

Sample 498A-9, CC includes pure nannoflora with $C$. leptopora, $H$. kamptneri, D. aff. brouweri, Sphenolithus sp., and Reticulofenestra pseudoumbilica. These occur down to the lowermost middle Miocene. Samples 498A-10-3, 71-73 cm to 498A-10,CC, belonging to the lower middle Miocene $S$. heteromorphus Zone, contain index species $D$. exilis, $S$. moriformis, and some others.

The nannoplankton assemblage of the lower part of this interval is correlated with the lower Miocene $H$. ampliaperta Zone and includes $H$. ampliaperta, $S$. heteromorphus, D. deflandrei, D. exilis, S. moriformis, Pontosphaera vigintiforata. Sample 498A-12,CC contains reworked Eocene D. barbadiensis, also. The Miocene assemblages of this interval, and particularly of Core 15 , are shallow-water assemblages.

\section{GEOCHEMISTRY}

\section{Organic Geochemistry}

This site is located about 1.2 miles from the first site drilled on Leg 67 (Site 494); it was thus anticipated that the composition and quantities of gaseous components would be similar to those already encountered. The methods employed for detection of hydrocarbons were the same as those described for Site 496.

The methane-ethane ratios for Hole 498A gas samples are shown in Figure 8. At about 158 meters, the ratio begins to decrease regularly with depth. Core 15 $(307.0-316.5 \mathrm{~m})$ contained gaseous hydrocarbons that yielded a methane-ethane ratio of 417 and resulted in the termination of drilling at Hole 498A. As Core 15 was laid down to remove the core catcher, a white vapor escaped from the end of the barrel. The core catcher was removed and several pieces of ice and icy sediment fell to the deck. These pieces were quickly placed in a sealed vessel fitted with a pressure gauge and allowed to come 


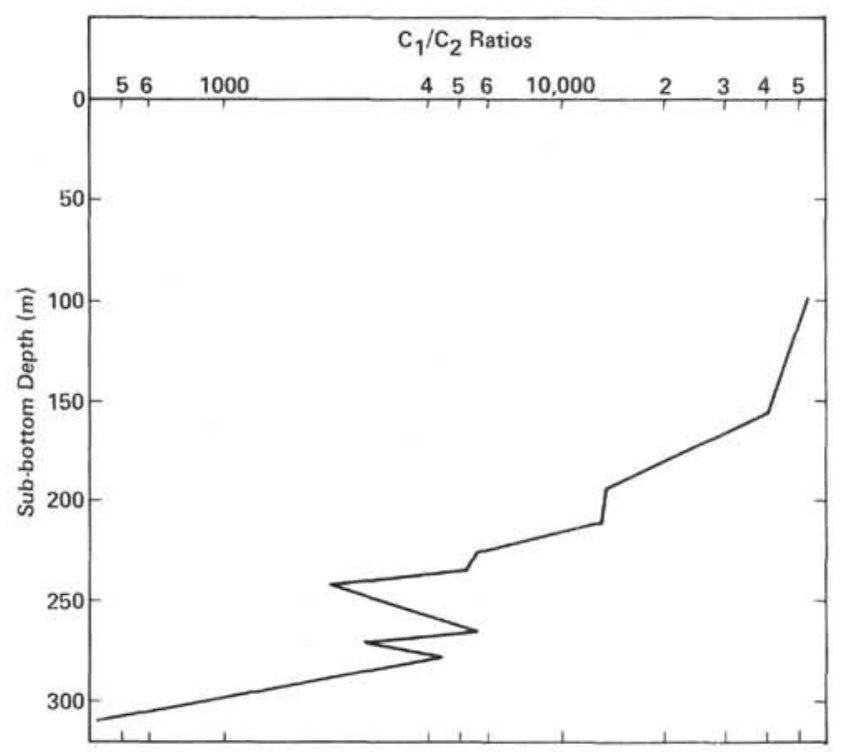

Figure 8. Methane-ethane ratios at Hole 498A.

to ambient temperature. The pressure that resulted from this exercise was $172 \mathrm{psi}$; later the volume of the sediment was determined to be approximately $100 \mathrm{~cm}^{3}$. Gas samples taken from the pressure vessel had a methaneethane ratio similar to that obtained by sampling through the liner of Core 15.

Figure 9 shows the approximate $P-T$ conditions at Hole 498A; more precise positioning within the hydrate stability field is difficult without temperature data. As at Site 497 , the $P-T$ conditions place Hole $498 \mathrm{~A}$ well within the hydrate zone. These physical conditions, the quantities of gas released from icy sediment, and visual observation indicate hydrates were being cored and recovered at Hole 498A.

Methane and ethane concentrations as a function of depth are shown in Figure 10. Methane content appears to be similar to other slope sites drilled on Leg 67 -about $75 \%$ to $80 \%$ (of total gas sampled). Marked deviations from the $75 \%$ to $80 \%$ range are due to sampling problems caused by poor core recovery. Obtaining suitable gas data by sampling through the liner is also dependent on sufficient sediment being present in the liner to form a good seal. Many times these conditions were not satisfied at this site.

Figure 11 shows isobutane and neopentane distribution. All samples had more neopentane than isobutane. At Holes 494 and 494A, neopentane and isobutane concentrations were such that a relationship was proposed for the two species. If neopentane suffers loss of one of its four methyl groups, isobutane would be the resultant species. Samples at other Leg 67 sites have failed to confirm the proposed relation, and it appears that these two components are randomly distributed in sediments of this particular slope.

\section{Inorganic Geochemistry}

Only three samples were collected for the shipboard interstitial water program at Holes 498 and 498A. Much

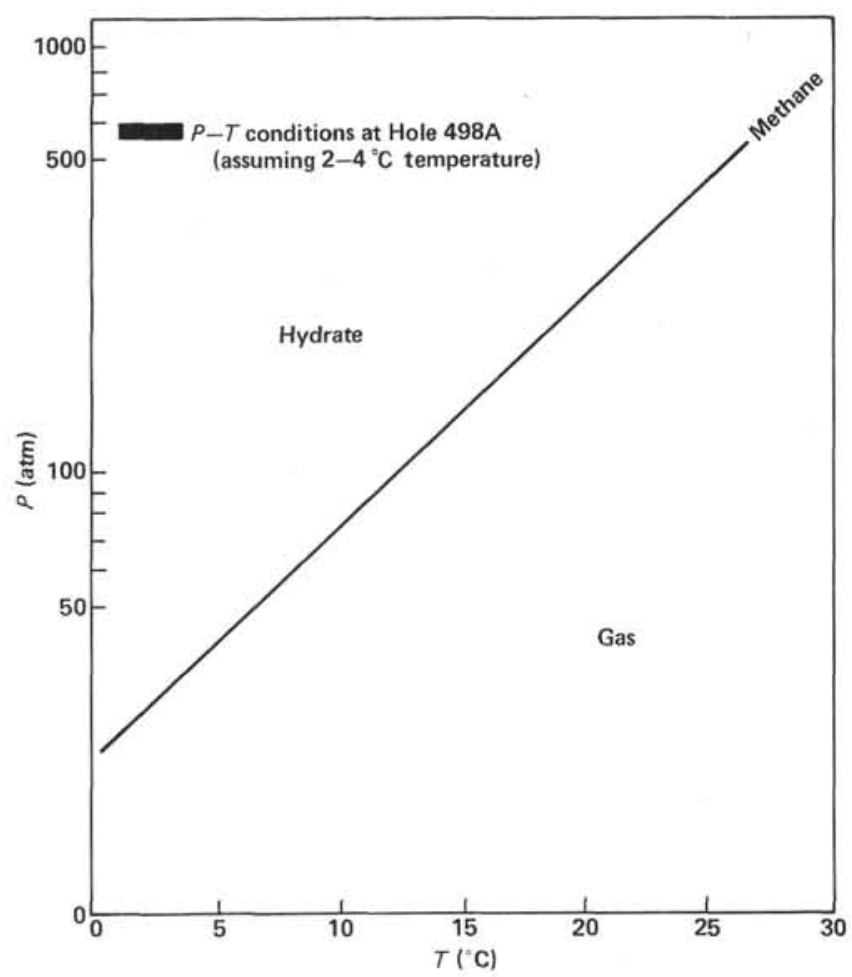

Figure 9. Pressure-temperature $(P-T)$ stability field of methane hydrate and $P-T$ conditions at Hole 498A.

of Hole 498A was washed instead of cored, and no samples were recovered. Also, recovery was poor in many of the cores below the washed interval.

\section{SUMMARY AND CONCLUSIONS}

A preliminary compilation of bathymetry from Kana Keoki seismic records suggested that Site 494 may have been located in a zone of faulting transverse to the strike of the trench. However, this interpretation does not concur with data from a Seabeam survey (Aubouin et al., this volume). The Kana Keoki geophysical data available at the time of site selection suggested a less faulted but structurally identical position along strike from Site 494 . At Site 498 , we drilled about $1.8 \mathrm{~km}$ eastsoutheast and along strike from Site 494 to fill the gaps in the stratigraphic section at Site 494 and to penetrate into the presumed underlying oceanic section. The recovery of gas hydrate caused us to abandon the site prior to reaching depths greater than penetrated at Site 494.

The mud and mudstone from the top 200 meters at Site 498 resemble those at Site 494. Abundant biogenic Pleistocene sediment transported from upslope is underlain by a Miocene unit of similar lithology. But the Miocene lithology at Site 498 is unlike that of the lithology of equivalent-age rock at Site 494 . The unbrecciated part of the section is dark olive gray mudstone, although chips of the familiar blue gray Miocene mudstone of Site 494 are abundant in the drilling breccia, which constitutes most of the recovered material. Additionally, at Site 498, the Miocene section is thicker than 

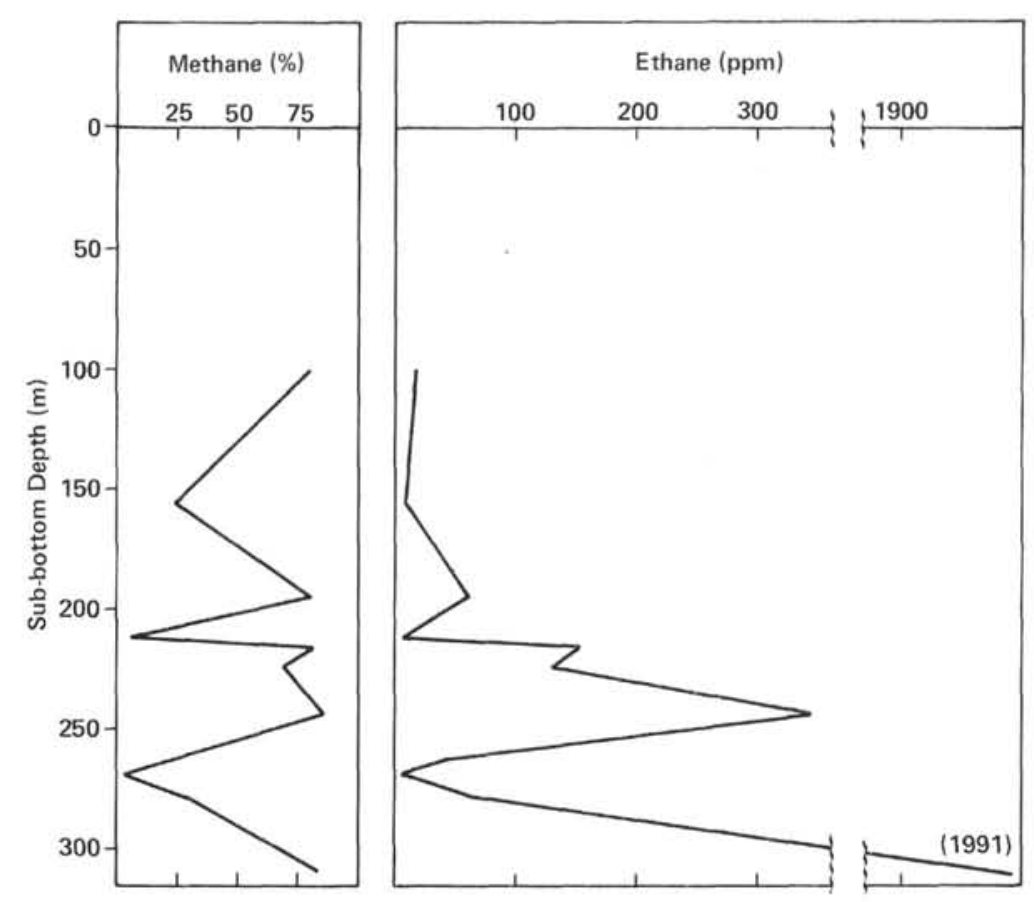

Figure 10. Methane and ethane concentrations at Hole 498A. (Maximum ethane value $=19.91$.

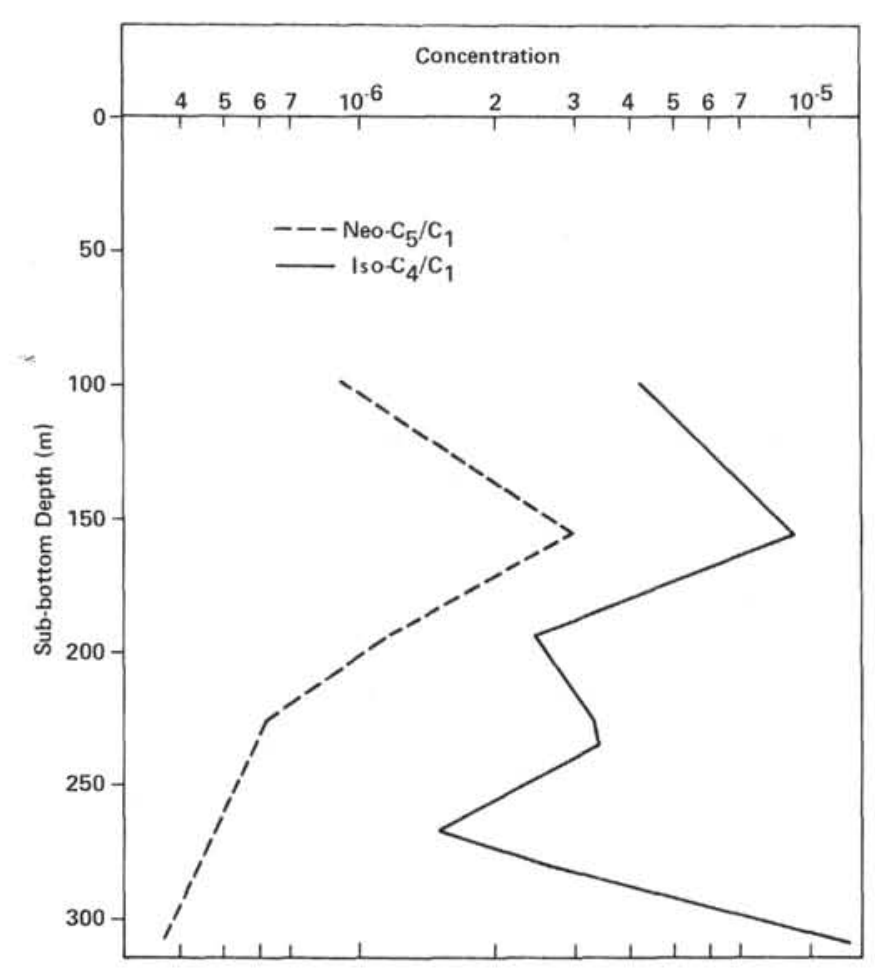

Figure 11. Neopentane and isobutane concentrations at Hole 498A.

at Site 494 . The poor core recovery and poor drilling conditions below 200 meters at Site 498 indicate that fracturing is well developed.

The disparity between the Miocene lithologies at these two sites, $1.8 \mathrm{~km}$ apart, indicates a degree of variability in rocks and ages along strike. The regularity of hori- zonal reflections in the seismic records gives a deceptively simple picture of the structure of the lower slope.

The biostratigraphy of the site appears disordered in part by poor recovery and in part by brecciation during drilling. In three intervals, the ages are repeated, and in two cases this can be explained by the sampling of a mixture of drilling chips rather than of a coherent core. The third repeated age sequence may have been caused by reworking of older blue gray mudstone or by minor reverse faulting.

Gas hydrates were encountered at about 310 meters. The single occurrence of hydrates was accompanied by a rapid decrease of the methane-ethane ratio. The presence of hydrates was confirmed by measuring the pressure as the hydrate came to ambient temperature and, from this, calculating the relative volumes of gas and water.

The similarity of Pliocene and Pleistocene drape of hemipelagic sediment at Sites 494 and 498 is indicative of comparable structural histories during this time inter$\mathrm{val}$, and the differences between Miocene lithologies at equivalent depths may reflect the relief of the Pliocene/ Miocene unconformity observed at Site 494. The distinctive blue gray Miocene mudstone from below the unconformity at Site 494 occurs as clasts in the olive gray Miocene slope sediments of Site 498. Perhaps Site 494 was on high ground that did not collect slope sediments until the Pliocene, whereas Site 498 was on low ground where the slope sediments ponded continuously. Alternatively, tectonic deformation may have caused the difference. Whether the cause of the difference between Miocene lithologies is tectonic or sedimentary, there is no indication in the seismic record of an unconformity or a fault between the sites. 

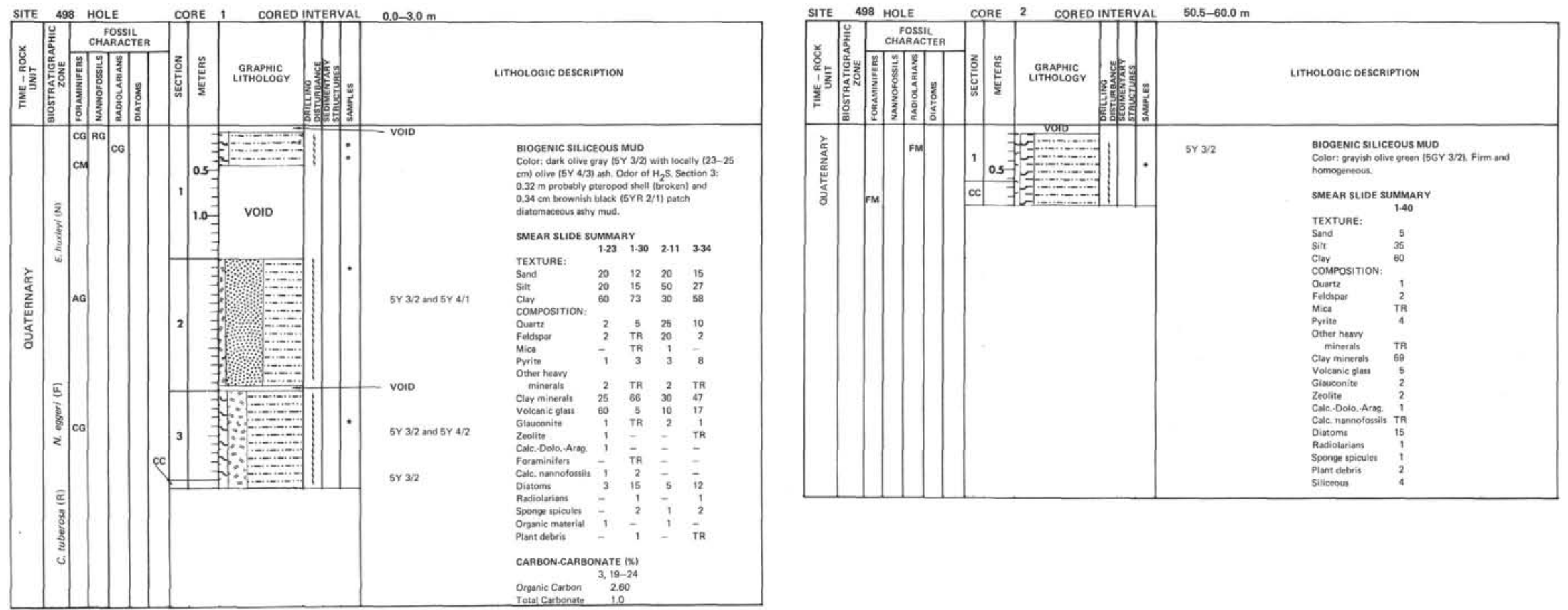

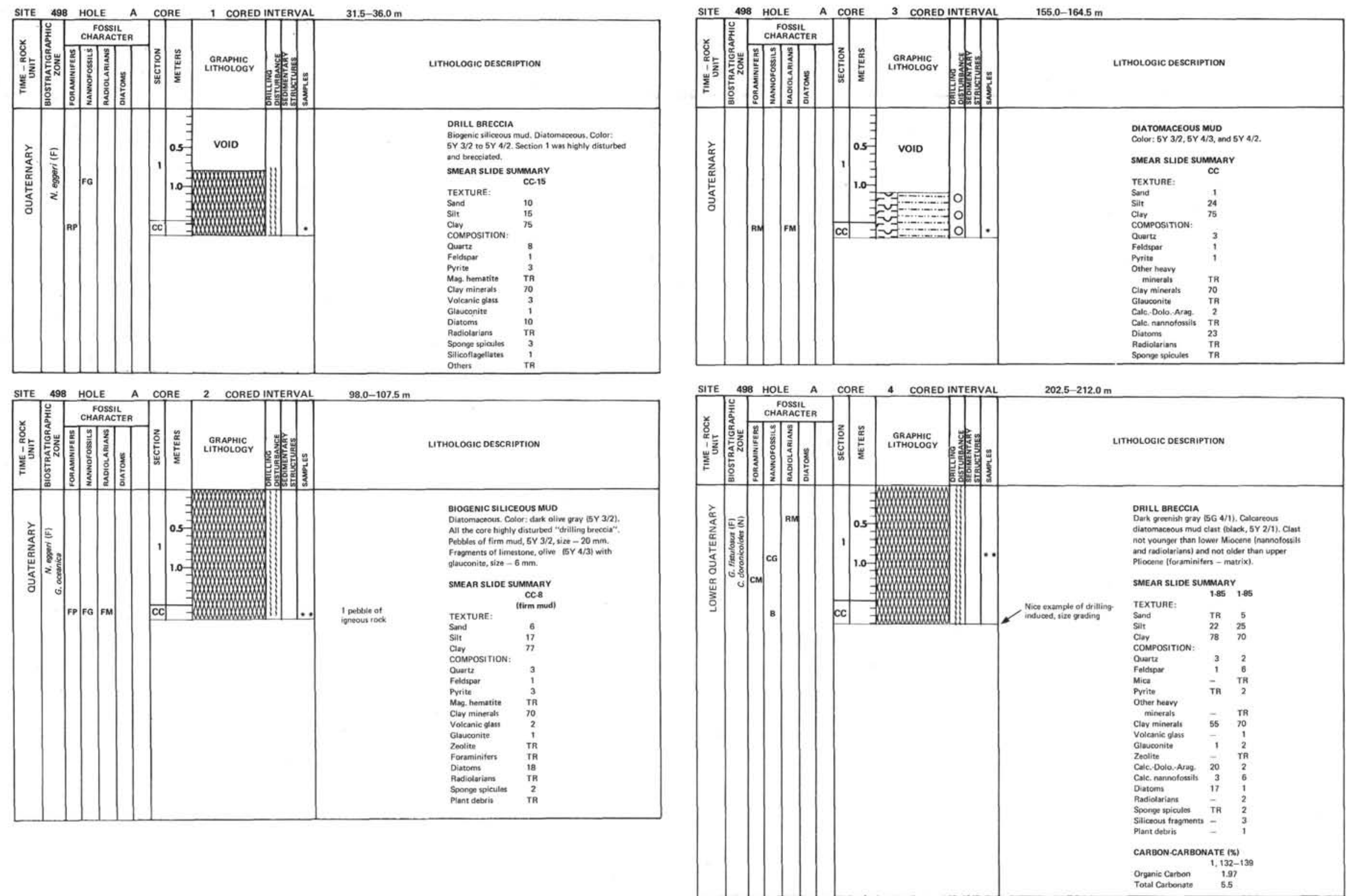

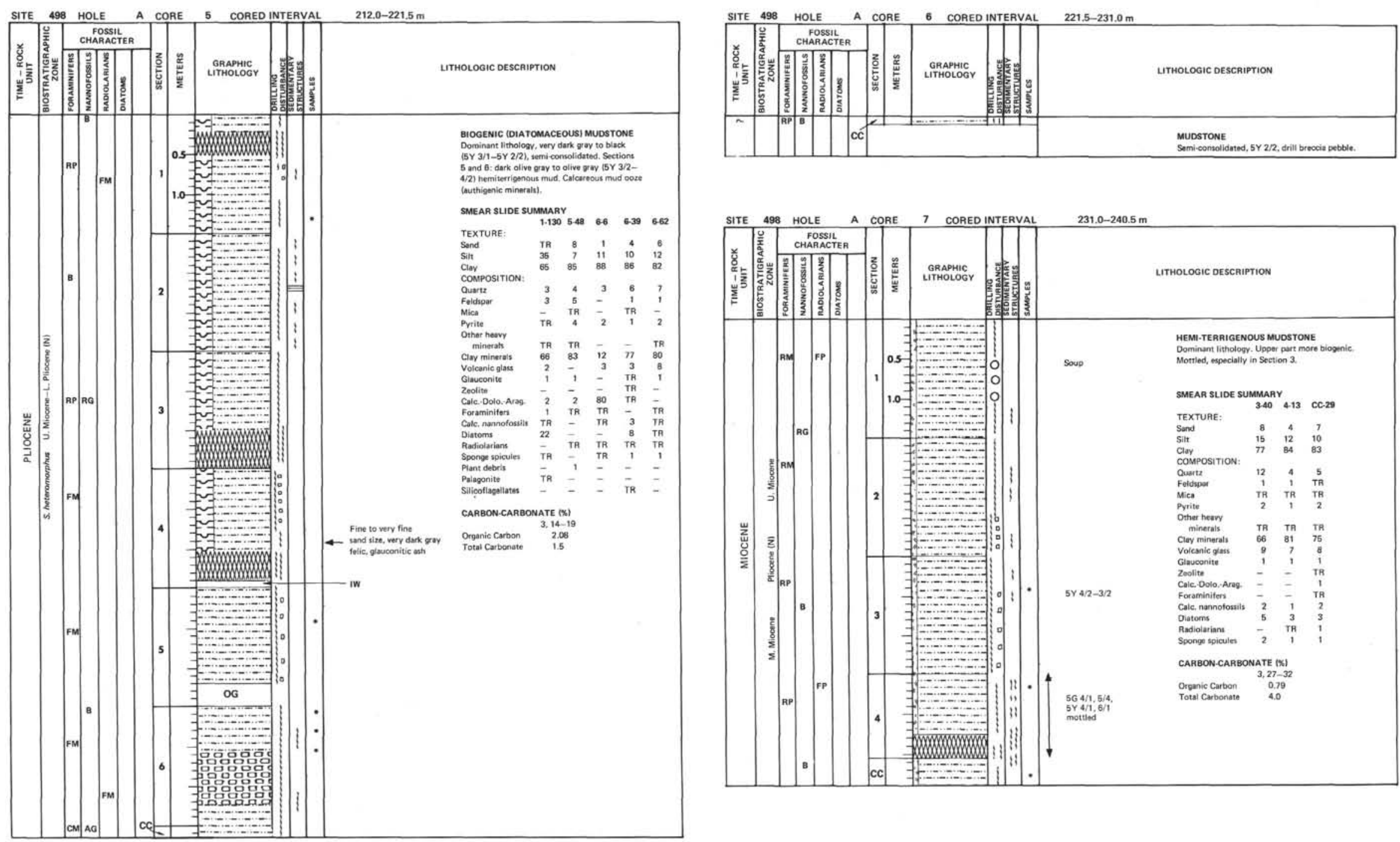

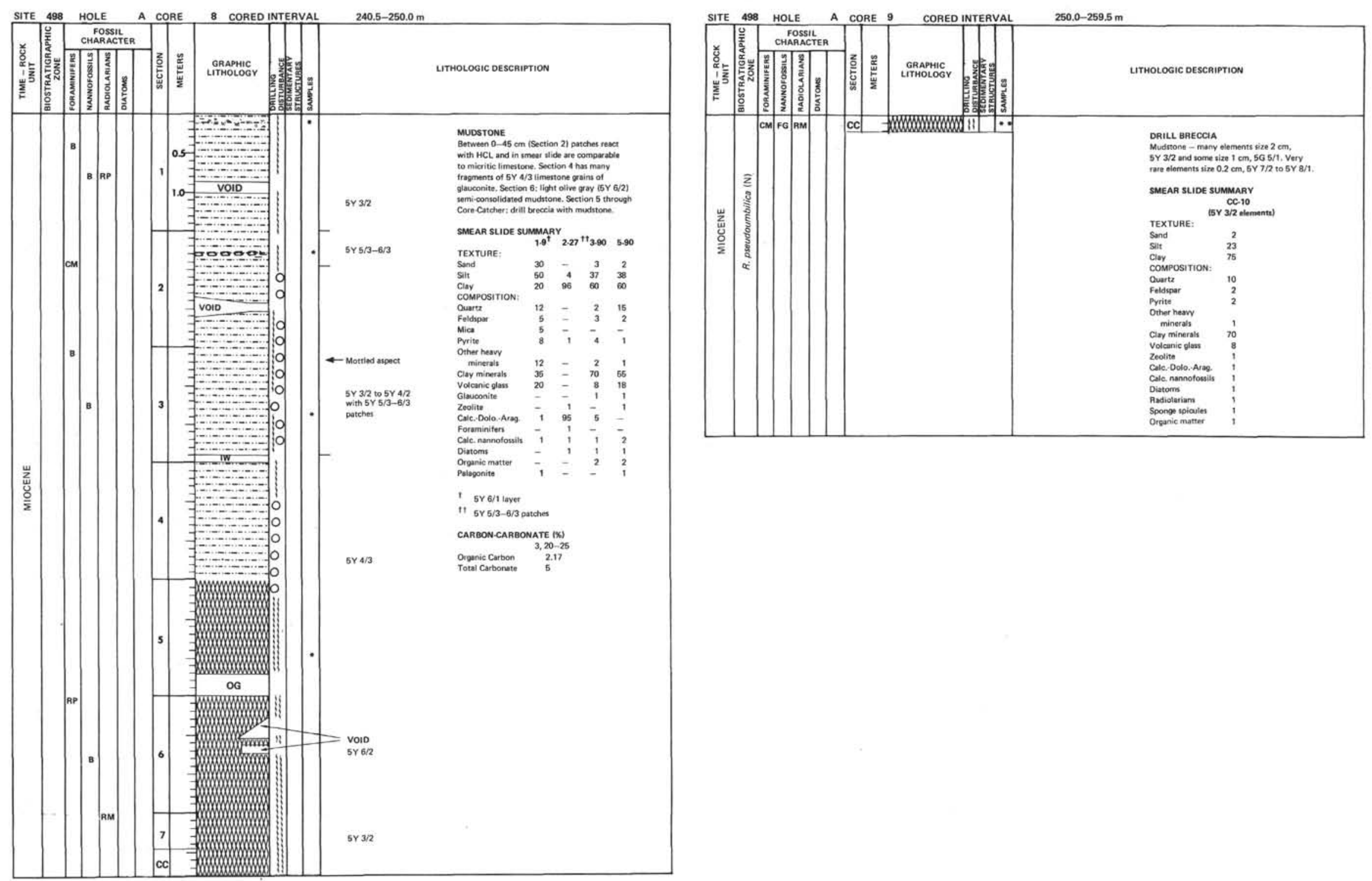

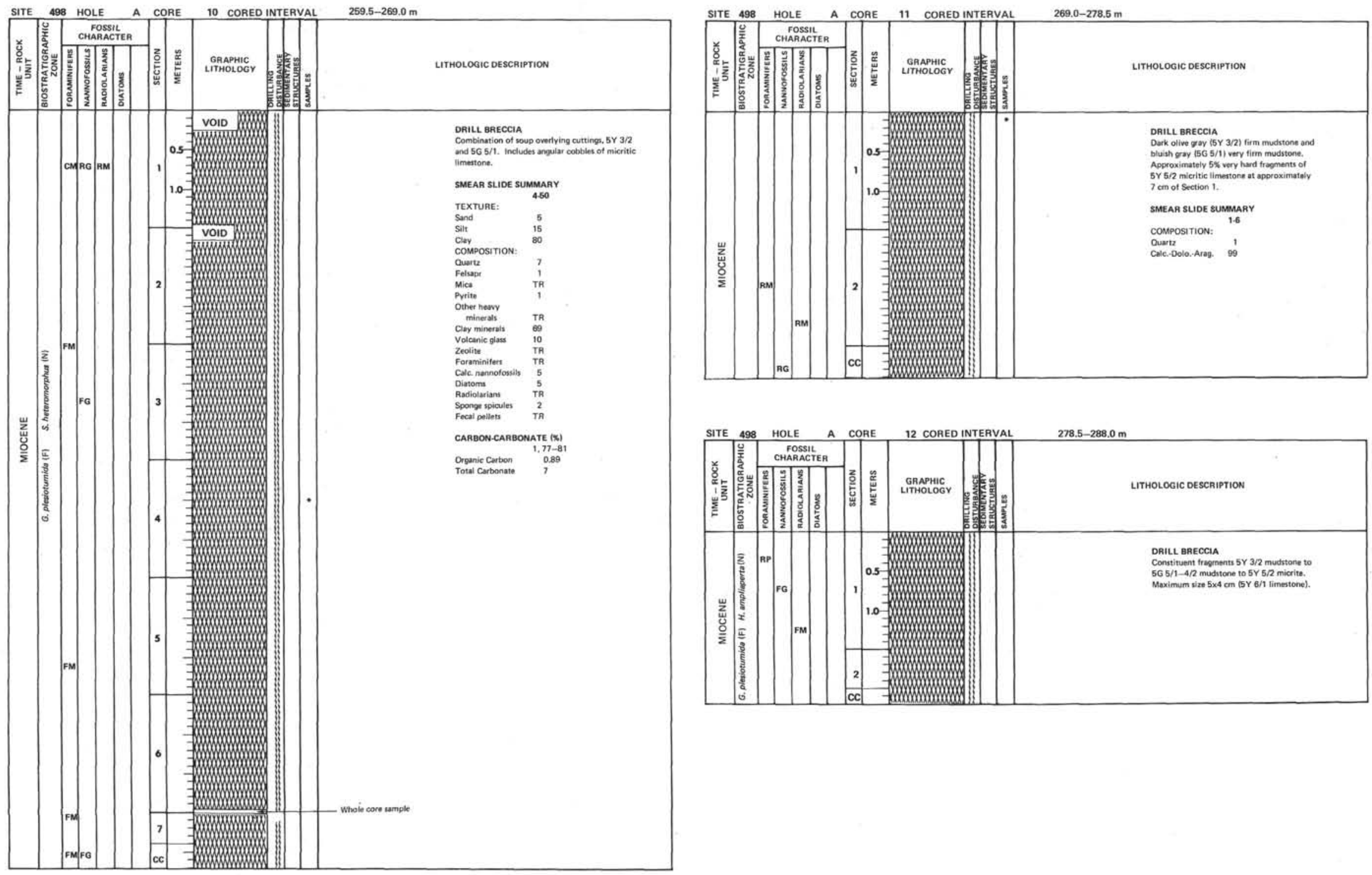


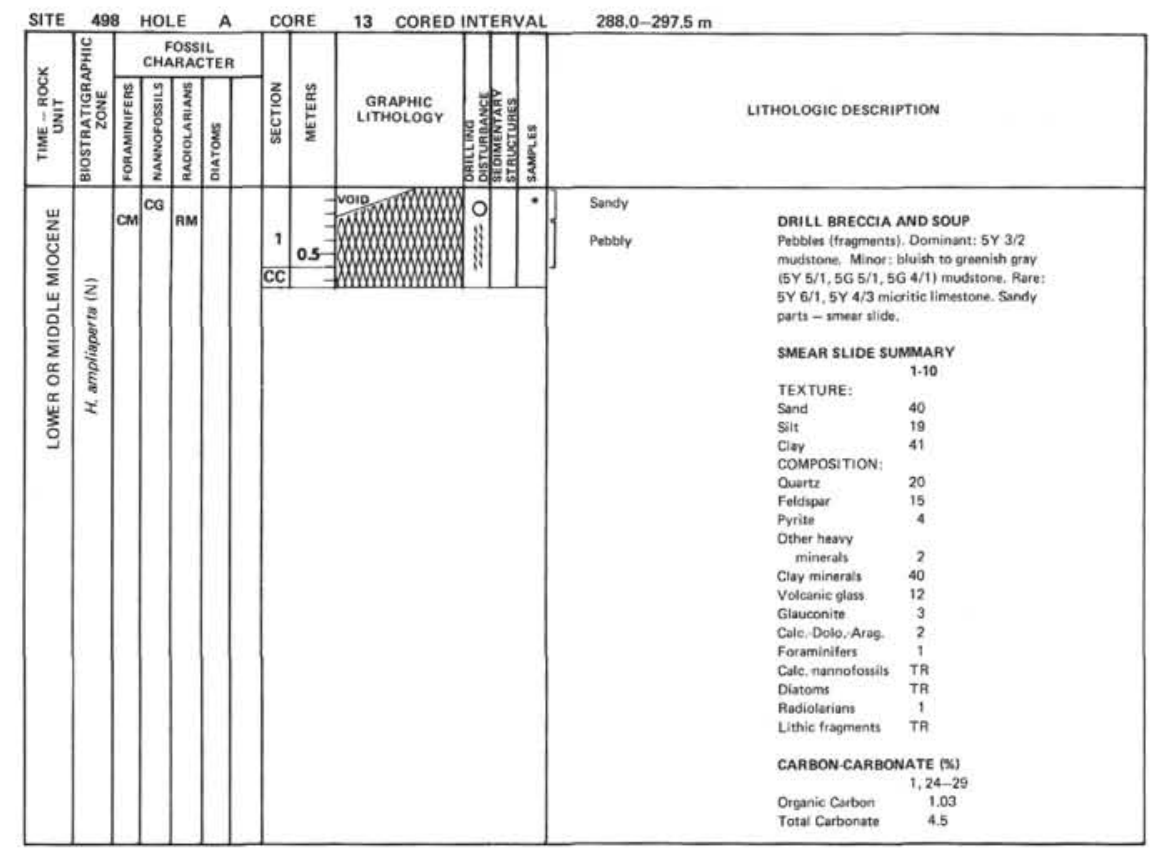

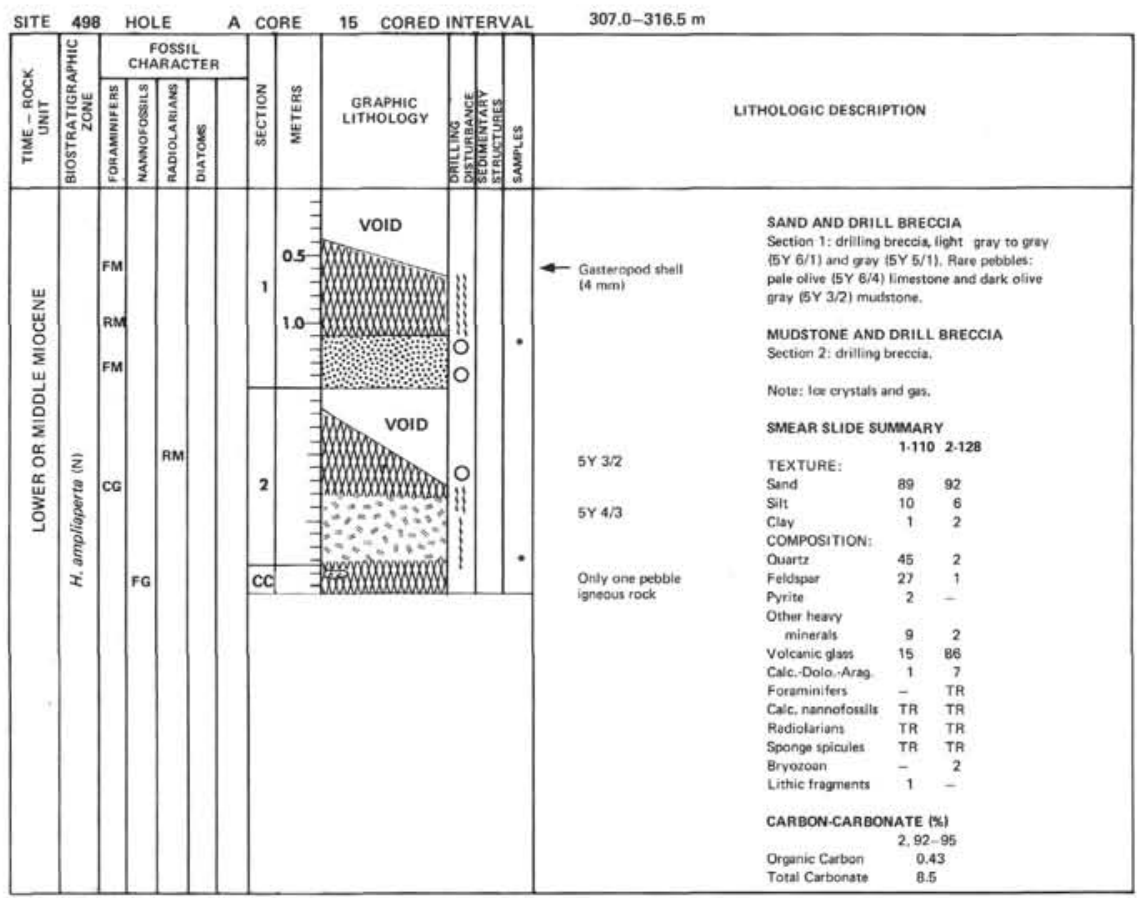

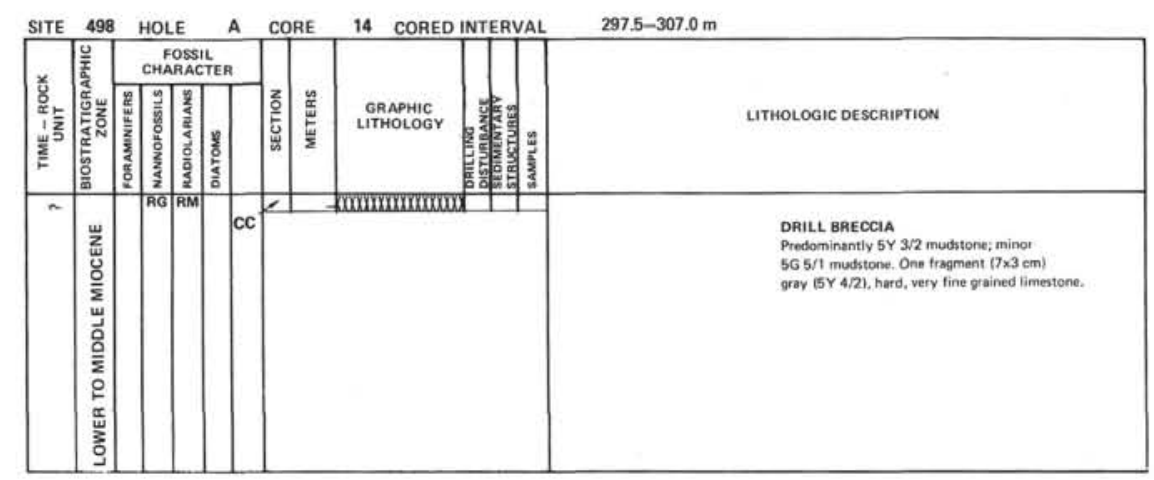




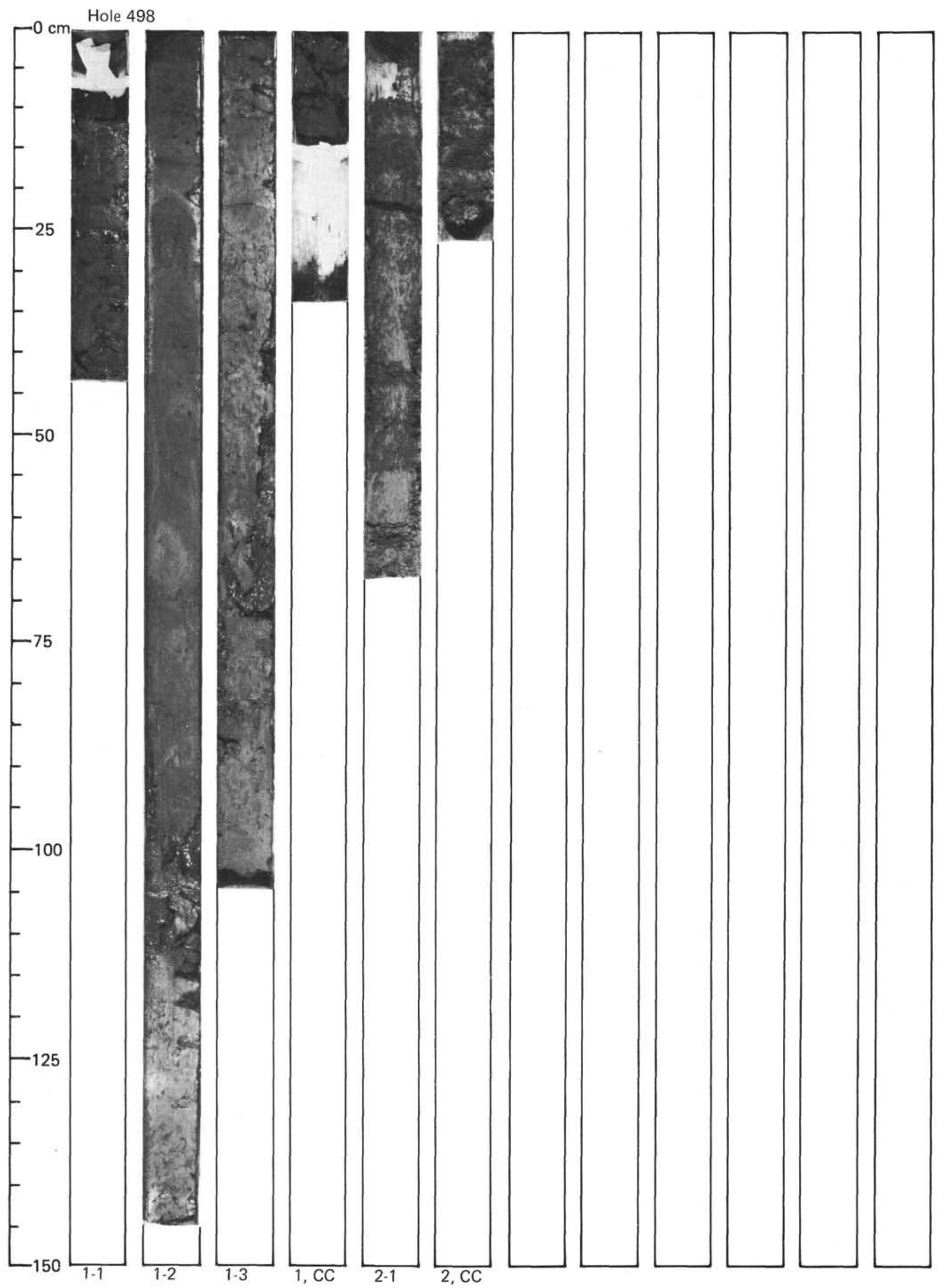




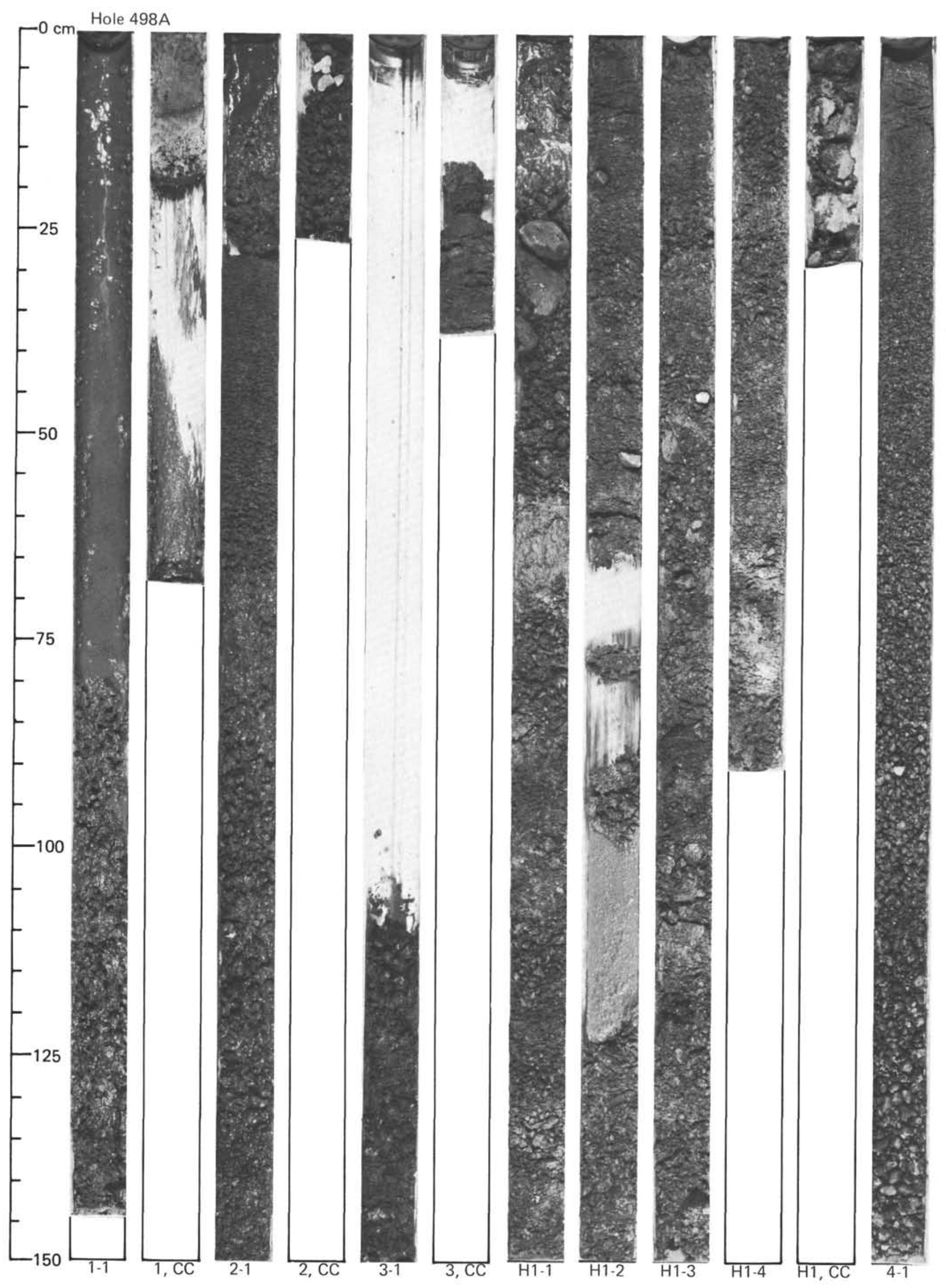




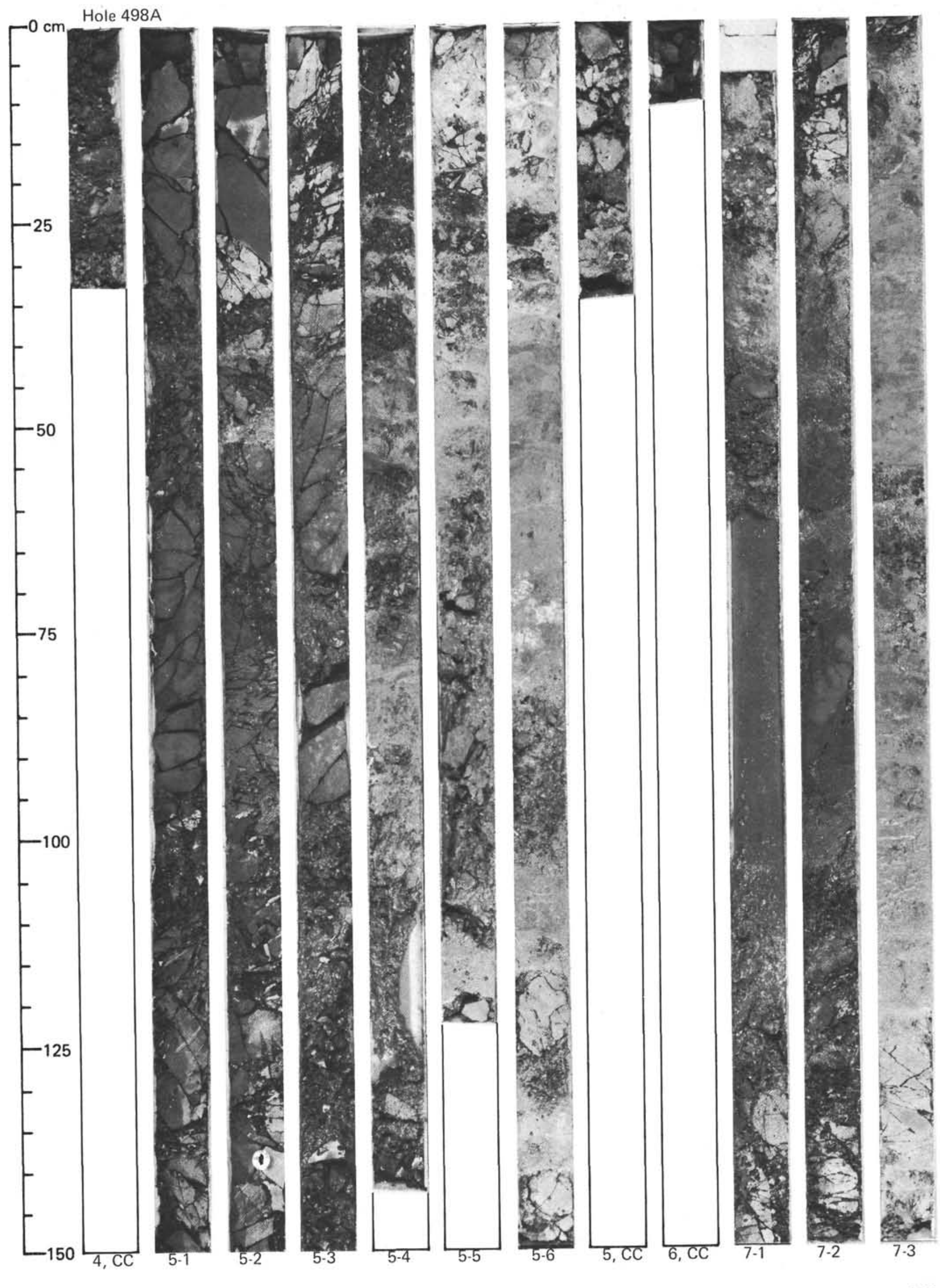




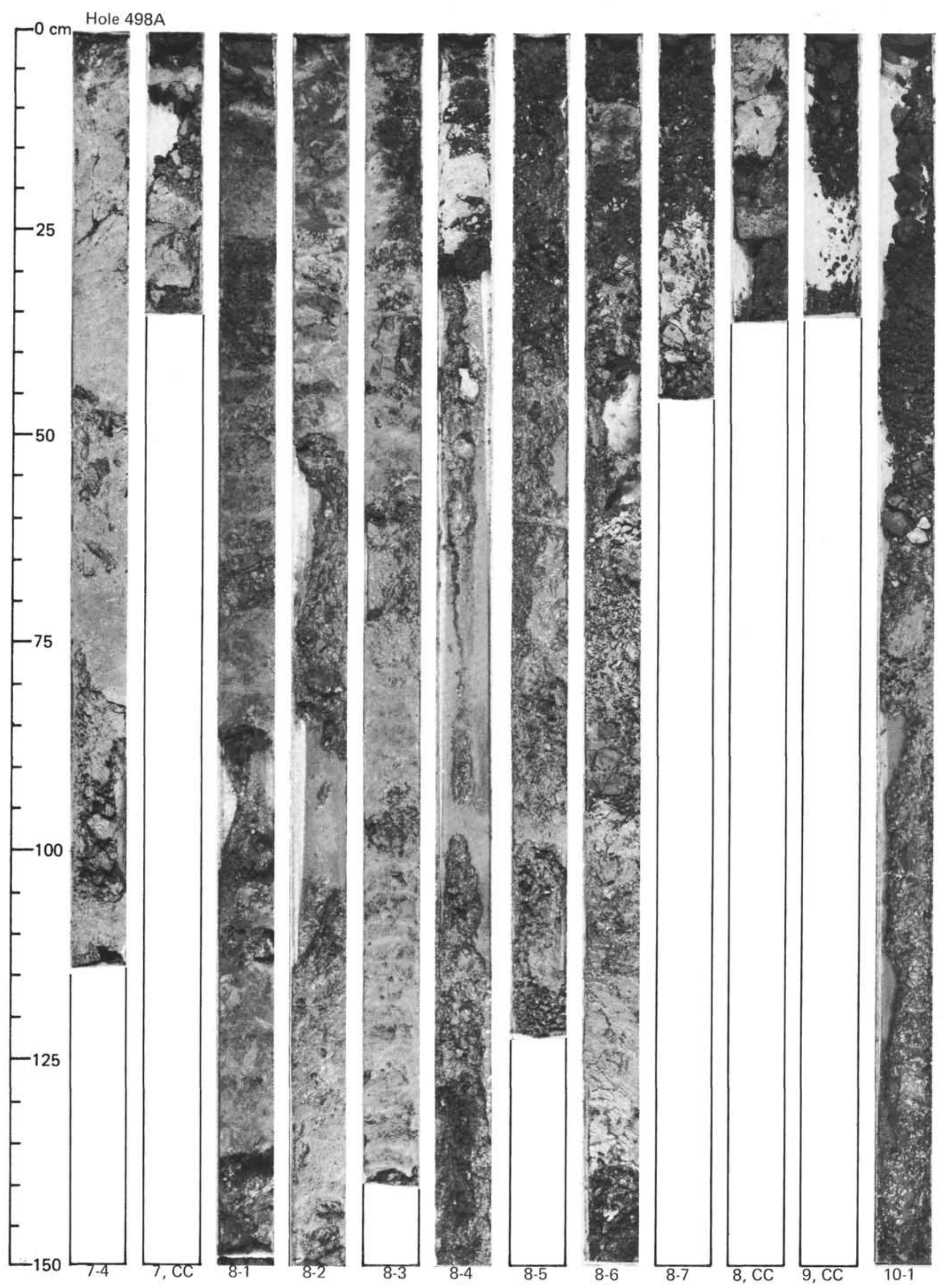




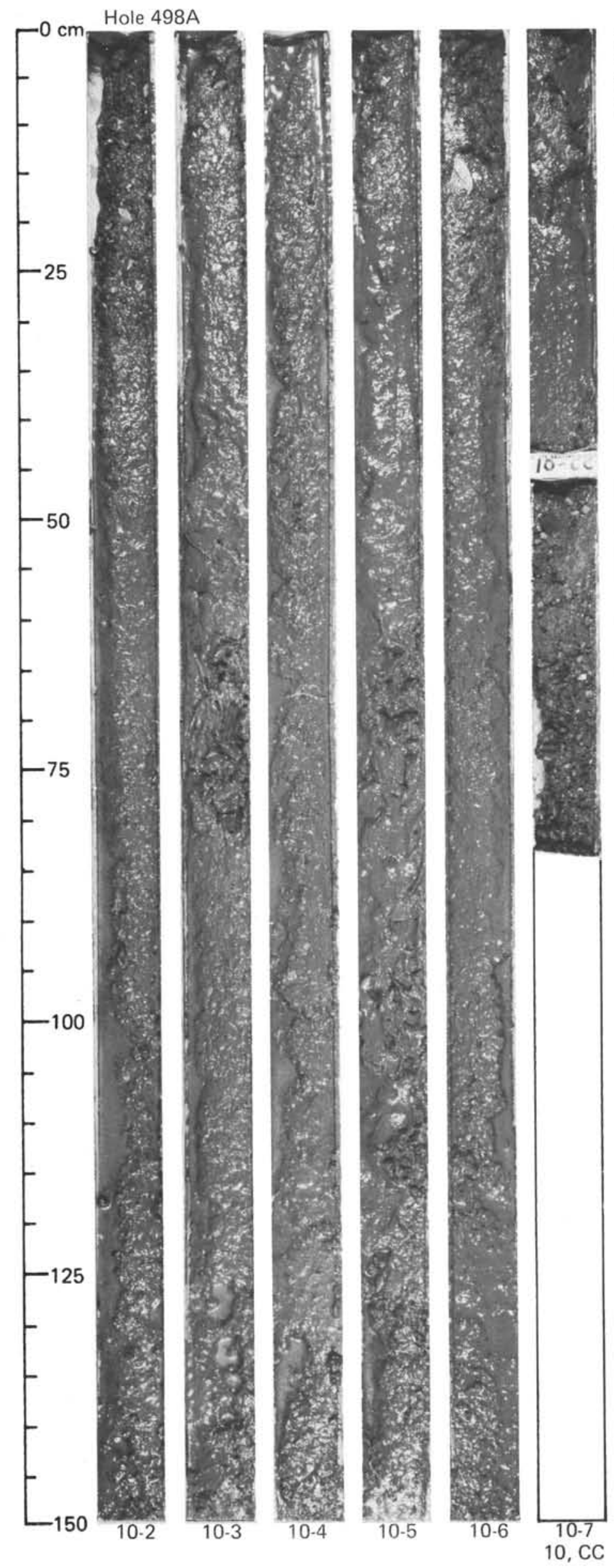

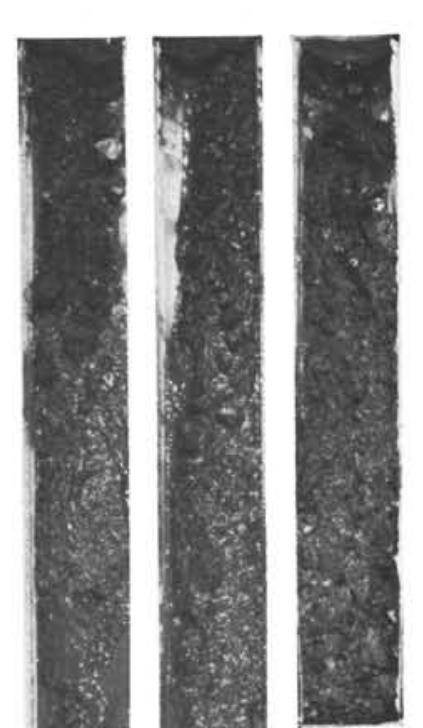
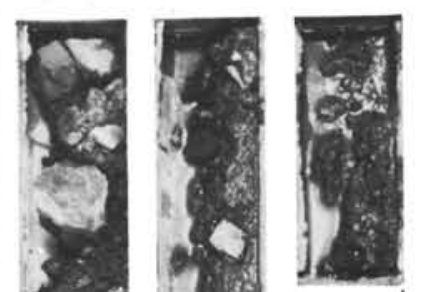

15

की

(5)

19.

bivis

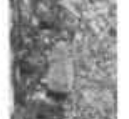

ing

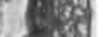

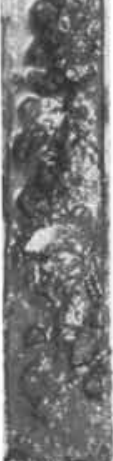

Jim

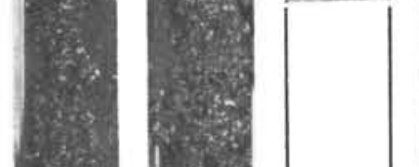

6)

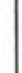

4.

in

iv

ins

20:



5.

.

$\frac{6}{8}$
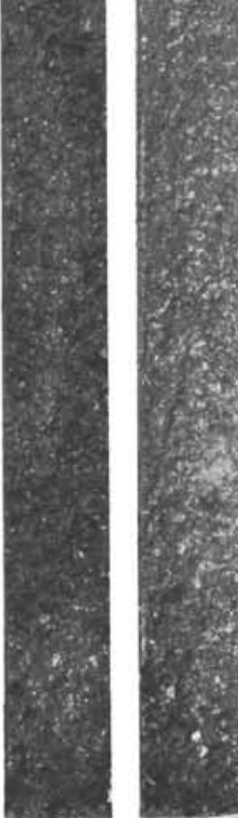

11.1

11.2
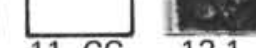

12.2

$12 \mathrm{CC}$ 


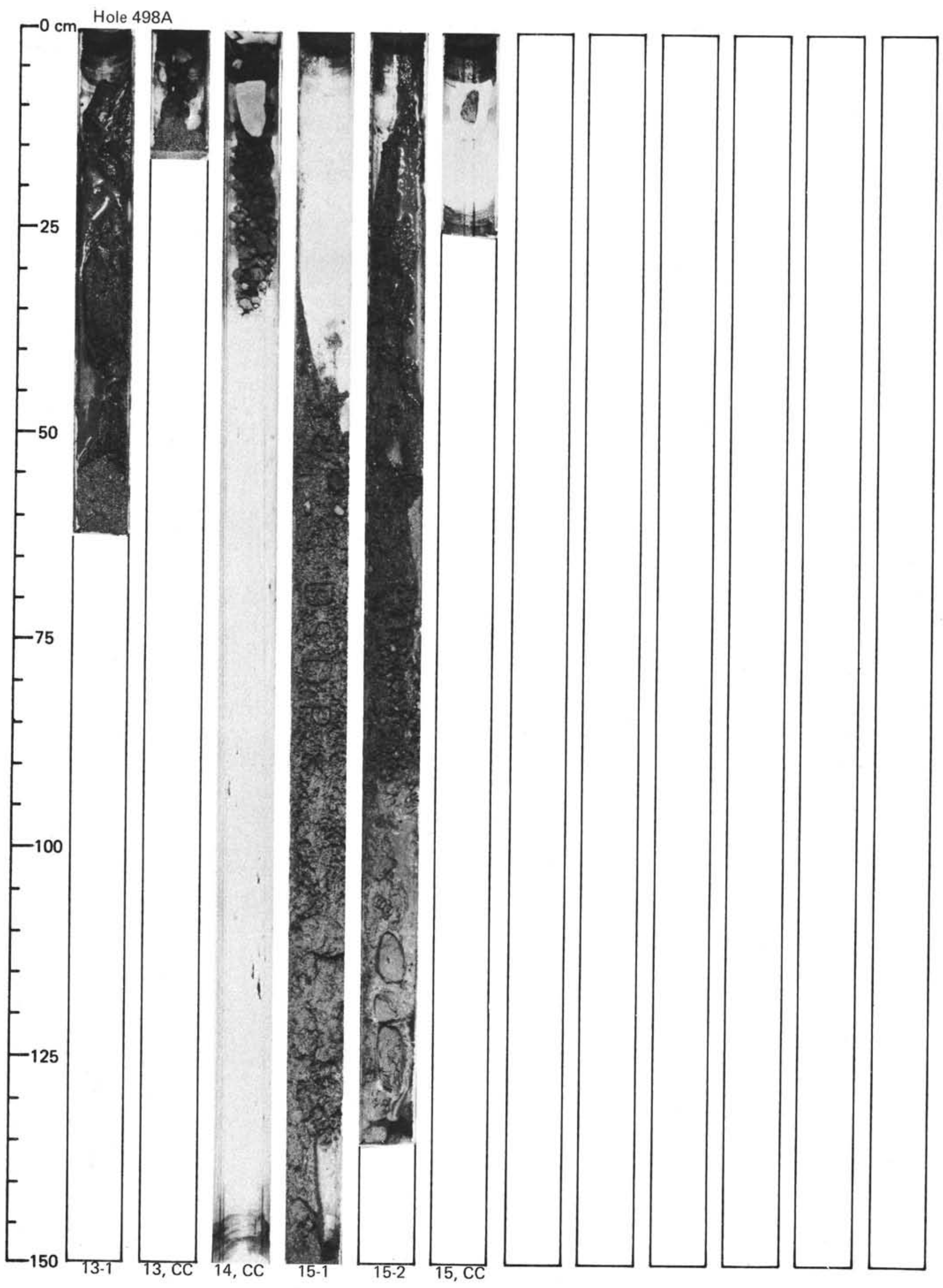

